\title{
Integration of Internal Control and Financial Statement Audits: Are Two Audits Better than One?
}

\author{
Lori S. Bhaskar \\ Assistant Professor \\ Kelley School of Business \\ Indiana University \\ lbhaskar@indiana.edu
}

\author{
Joseph H. Schroeder \\ Assistant Professor \\ Kelley School of Business \\ Indiana University \\ jhschroe@indiana.edu
}

\author{
Marcy L. Shepardson \\ Assistant Professor \\ Kelley School of Business \\ Indiana University \\ shepardm@indiana.edu
}

April 26, 2018

We appreciate helpful suggestions and comments from Abraham Akresh, Terrence Blackburne, Scott Bronson, Lauren Cunningham, Mike Ettredge, Lynford Graham, Elizabeth Gutierrez, Chris Hogan, Bill Kinney, Sarah McVay, Melanie Millar, Miguel Minutti-Meza, Christine Nolder, Tom Omer, Susan Scholz, Jim Wahlen, Tiffany Westfall, Teri Yohn and the workshop/conference participants at Baylor University, Indiana University, University of Iowa, University of Kansas, Universidad de Chile, University of Washington, the 2015 Indiana University Accounting Leading Scholar Symposium Series, the 2016 Kansas/Deloitte Auditing Symposium, the 2016 International Symposium on Auditing Research, the 2017 AAA Audit Midyear Meeting, the 2017 EAA Annual Congress, and the 2018 MAC Accounting Conference. 


\title{
Integration of Internal Control and Financial Statement Audits: Are Two Audits Better than One?
}

\begin{abstract}
The quality of financial statement (FS) audits integrated with audits of internal controls over financial reporting (ICFR) depends upon the quality of ICFR information used in, and its integration into, FS audits. Recent research and PCAOB inspections find auditors underreport existing ICFR weaknesses and perform insufficient testing to address identified risks, suggesting integrated audits - in which substantial ICFR testing is required - may result in lower FS-audit quality than similar FS-only audits. We compare a 2007 - 2013 sample of small, U.S. public company firm-years receiving integrated audits (accelerated filers) to firm-years receiving FS-only audits (non-accelerated filers) and find integrated audits are associated with higher likelihood of material misstatements and discretionary accruals, consistent with lower FS audit quality. We also find evidence of (1) auditor judgment-based integration issues and (2) low-quality ICFR audits harming FS audit quality. Overall, results suggest an important potential consequence of integrated audits is lower FS audit quality.
\end{abstract}




\section{INTRODUCTION}

Audits of internal controls over financial reporting (ICFR) have been required for larger U.S. public issuers since 2004 (U.S. Congress 2002). In addition to requiring audited disclosures about ICFR quality, this mandate has resulted in a fundamental shift in how financial statement (FS) audits are performed when ICFR audits are required because they must be performed "in an integrated manner” (PCAOB 2007). ${ }^{1}$ FS audits integrated with ICFR audits yield more information about internal control quality and related risks of material misstatement than similar FS-only audits, potentially leading to higher quality FS audits. However, FS audit quality in integrated audits depends, in part, on how well auditors integrate the ICFR and FS audits and the quality of ICFR audit conclusions, about both of which the Public Company Accounting Oversight Board (PCAOB) and independent research have identified concerns (PCAOB 2012, 2013; Rice and Weber 2012). Thus, while there is potential for integrated audits to improve FS audit quality, evidence from PCAOB inspection findings and archival research implies the opposite: that integrated audits also have the potential to harm FS audit quality.

We therefore address what we contend is an essential, unanswered question: how does having an audit of internal controls that is integrated with the financial statement audit affect financial statement audit quality? We exploit that accelerated filers have integrated audits whereas non-accelerated filers have FS-only audits and first address whether integrated audits affect FS audit quality. A finding that integrated audits are associated with improved FS audit quality over FS-only audits of similar firms could bolster support for the ICFR audit mandate. However, a finding that ICFR audits weaken FS audit quality would add to already high ICFR audit costs and should be important to the Securities and Exchange Commission (SEC) as they

\footnotetext{
${ }^{1}$ U.S. accelerated filers, public issuers with more than $\$ 75$ million in public float (equity available to outsiders), have both a FS and ICFR audit and non-accelerated filers have a FS audit and provide unaudited ICFR disclosures.
} 
consider effects of increasing the number of firms qualifying for ICFR audit exemption (SEC 2016). Next, we develop predictions about two conditions under which integrated audits could negatively affect FS audit quality, which is important for auditors in implementing high-quality integrated audits and the PCAOB in setting high-quality auditing standards.

First, we predict increased control reliance in integrated audits increases opportunities for judgment-based integration issues, which negatively affect FS audit quality. FS auditors use a combination of control and substantive testing to limit audit risk, the risk the auditor provides an inaccurate unqualified opinion, and control reliance occurs when auditors obtain some assurance by testing the company's internal controls. FS-only auditors base control reliance decisions on effectiveness and efficiency assessments based on minimum requirements to understand control system design, whereas integrated auditors' FS audit control reliance decisions are conditional on required ICFR audit control testing. We therefore expect integrated auditors leverage costly ICFR audit testing by relying more on controls in the FS audit than they would absent the ICFR audit. In turn, we expect greater control reliance increases opportunities for judgment-based integration issues, including inappropriately or insufficiently adjusting substantive testing for identified risks and improperly applying misaligned auditing standards.

Experimental research and PCAOB inspections each indicate FS auditors fail to sufficiently adjust substantive procedures following increases in inherent and control risks (Allen, Hermanson, Kozloski, and Ramsay 2006; Asare, Fitzgerald, Graham, Joe, Negangard, and Wolfe 2013; PCAOB 2008, 2009, 2015). Furthermore, archival research finds even when auditors conclude ICFR is low quality ${ }^{2}$, which should result in increased testing to identify material misstatements, financial reporting quality still suffers (e.g., Doyle, Ge, and McVay

\footnotetext{
${ }^{2}$ FS auditors can rely on ICFR when they conclude controls are ineffective, overall, in the ICFR audit because reliance decisions in the FS audit are made at the account or assertion level.
} 
2007a; Ashbaugh-Skaife, Collins, Kinney, and LaFond 2008). In addition, the differences in timing between ICFR and FS audit opinions may lead to reliance on controls that are effective as of year-end but not for the entire year, such that ICFR audit testing is insufficient for FS audit control reliance. Together, increased control reliance in integrated audits provides opportunities for judgment errors identified in prior research and due to misalignment of auditing standards, which we predict are associated with lower FS audit quality.

Second, we predict low-quality ICFR audits incrementally impair FS audit quality because "the level of substantive testing is predicated on the auditor's [ICFR] assessment" (PCAOB 2012). If ICFR audits are low quality, control information identified in ICFR audits and used in FS audit risk model estimation will bias control risk estimates, in turn leading to insufficient substantive testing. PCAOB inspection and academic evidence about ICFR audit quality is generally negative. The PCAOB disclosed that $22 \%$ of audits inspected in 2011 did not obtain sufficient evidence to support the ICFR audit opinion and consequently, $82 \%$ of those audits did not adequately support the FS audit opinion (PCAOB 2013a). In a sample of firms with known material weaknesses, Rice and Weber (2012) conclude only 32.4\% of material weaknesses were reported. Moreover, when integrated auditors incorrectly conclude there are no material weaknesses, based on psychology theory and prior auditing research (Kelley 1971; Tan 1995; Hatfield, Jackson, and Vandevelde 2011), we posit auditor involvement in ICFR audit conclusions may unintentionally bias auditors' subsequent judgments against concluding FS misstatements are material in order to avoid finding fault with their prior ICFR conclusions. We therefore posit low-quality ICFR audits are associated with incrementally lower FS audit quality. Using a 2007 - 2013 sample of small accelerated filers having integrated audits and a control group of non-accelerated filers having FS-only audits (all with less than \$150 million in 
market value of equity), we estimate whether and how FS audit quality differs between integrated and FS-only audits using three FS audit quality measures: material FS misstatements (identified via subsequently announced material restatements), all misstatements, and discretionary accruals. To test our predictions, we build on recent research (Acito, Hogan, and Imdieke 2015; Ge, Koester, and McVay 2017) and estimate whether firm-years are likely to have low ICFR audit quality, defined as disclosing no material weaknesses when we estimate at least one exists, and partition our sample into four comparison groups having similar likely and reported ICFR quality, which provides a matched sample of treatment and control firms. We then re-estimate our primary regressions within each group.

First, in cross-sectional regressions, firm-years having integrated audits are significantly more likely to be materially misstated, indicating a marginal effect of $0.023^{3}$ equaling $85.8 \%$ of the conditional probability of material misstatement, and have larger discretionary accruals than firms-years having FS-only audits. After controlling for low-quality ICFR audits, the likelihood of material misstatement remains higher and discretionary accruals remain larger for firms with integrated audits. Additionally, the likelihood of material misstatement is incrementally higher, with a marginal effect of 0.029 , or $112.7 \%$, and discretionary accruals are incrementally larger for firms with low-quality ICFR audits. Results provide strong evidence, across multiple proxies, that FS audit quality is lower in integrated than FS-only audits of similar firms, consistent with judgment-based integration issues and low-quality ICFR audits impairing FS audit quality.

Second, within each of the four comparison groups, we find firm-years having integrated audits are more likely to be materially misstated than those having FS-only audits. Within the

\footnotetext{
${ }^{3}$ For brevity, we only discuss material misstatement results, but results are consistent using all misstatements. Untabulated marginal effects are calculated as the change in predicted probability of outcome caused by changing independent variables from zero to one while holding control variables constant at their means. Percentages are smaller, albeit still economically large, when we scale by unconditional probabilities of misstatements.
} 
groups we estimate have high-quality ICFR disclosures, we find integrated audits disclosing at least one material weakness are associated with a marginal effect of 0.033 , or $70.5 \%$, on the conditional probability of material misstatement, and those disclosing no material weaknesses are associated with a marginal effect of 0.011 , or $127.6 \%$. In addition, those disclosing no material weaknesses report larger accruals. Thus, even when we estimate ICFR audit quality is high, we find lower FS audit quality in integrated audits, consistent with integration issues predictions. Finally, within the group we estimate has low-quality ICFR disclosures, we find integrated audits are associated with a marginal effect of 0.064 , representing $116.9 \%$ of the conditional probability of material misstatement.

We address three plausible alternate explanations for our results. First, we address concerns that integrated audits are more likely to identify control deficiencies, leading to the detection of prior period misstatements (a detection effect). For this explanation to have merit, integrated audits must either identify more control deficiencies or prior period restatements than similar FS-only audits. We find no evidence of increased material weakness disclosures or restatement announcements in firm-years with integrated audits, even when we assume material weakness identification leads to required restatements. In addition, if results are due to a detection effect, we would expect differences in misstatement likelihood from 2001 - 2003 between firms having integrated and FS-only audits in 2004 because integrated audits would detect more prior period misstatements. We find no differences. Finally, if results are due to a detection effect, we would not expect to find differences in discretionary accruals.

Next, prior research concludes some firms manipulate their public float to avoid ICFR audits (Gao, Wu, and Zimmerman 2009; Iliev 2010). If firms evading integrated audits do so because they rationally conclude compliance is net costly, self-selection effects could be biasing 
coefficients toward our results. ${ }^{4}$ Consistent with Gao et al. (2009) and Iliev (2010), we classify firm-years with FS-only audits and public float as of their second fiscal quarter between $\$ 65$ and $\$ 75$ million as potential evaders, and re-estimate all analyses excluding the potential evaders. All results remain statistically and economically similar.

In addition, if characteristics differ between firm-years with FS-only and integrated audits, including determinants of public float, and are correlated with both having an integrated audit and FS-audit quality measures, coefficients on our independent variables may be biased. Thus, we control for determinants of public float in all primary regressions and re-estimate our analyses in a sample of firm-years having integrated and FS-only audits matched by year on determinants of public float and find similar results. Additionally, using a difference in differences specification we find no difference in FS audit quality between accelerated and nonaccelerated filers prior to integrated audits, and FS audit quality worsens for firms implementing integrated audits compared to firms with FS-only audits throughout. Result are inconsistent with firm characteristics causing associations between integrated audits and FS-audit quality.

Our study identifies a previously unexamined consequence of integrated audits: lower FS audit quality. We contribute to literature addressing costs (e.g., Raghunandan and Rama 2006; Kinney and Shepardson 2011) and benefits (e.g., Schroeder and Shepardson 2016; Ge et al. 2017) of ICFR audits and expand on Iliev (2010) and Nagy (2010), which conclude FS reporting quality improved in the initial years of ICFR audits. Our examination, over a longer window and under the current auditing standards regime (AS5), draws opposite conclusions and identifies conditions under which integrated audits weaken FS audit quality. We also generalize and extend

\footnotetext{
${ }^{4}$ For example, if high-quality internal controls lead firms to accurately conclude compliance is net costly, then those firms taking actions to avoid compliance (those firms right below the threshold) may have lower misstatement likelihood and discretionary accruals due to improved controls rather than FS audit quality.
} 
Acito et al. (2015), which documents an increased association between low-quality ICFR audits and misstatements after the 2007 auditing standards change to AS5, by providing evidence that integrated audits are associated with worse FS audit quality as compared to FS-only audits. Finally, we build on Rice and Weber (2012) and Ge et al. (2017), which find ICFR disclosures are, on average, low quality by identifying an important implication of low-quality ICFR audits: reduced FS audit quality. In light of our findings, improving ICFR audit quality is necessary but not sufficient to mitigate detrimental integrated audit effects on FS audit quality; auditors and the PCAOB should also address how to improve integration of ICFR-related information into FS audits to improve overall integrated audit quality.

\section{BACKGROUND AND HYPOTHESIS DEVELOPMENT}

Since 2004, SOX Section 404(a) has required management provide an annual assessment and disclosure of ICFR quality and Section 404(b) has required an audit of ICFR for all U.S. public issuers with public float greater than $\$ 75$ million (U.S. Congress 2002), in addition to the FS audit required for all U.S. public issuers (U.S. Congress 1934). ${ }^{5}$ While the purposes of the two audit opinions are related and the audits must be integrated, their specific goals are distinct (Kinney, Martin, and Shepardson 2013). The FS opinion provides reasonable assurance about whether material misstatements do exist and the ICFR opinion provides reasonable assurance about whether material misstatements could exist. Specifically, the auditor's opinion on ICFR provides reasonable assurance about the existence of any material weaknesses, defined as "a deficiency, or combination of deficiencies, in internal control over financial reporting, such that there is a reasonable possibility that a material misstatement of the company's annual or interim financial statements will not be prevented or detected on a timely basis” (PCAOB 2007). In the

\footnotetext{
${ }^{5}$ The Section 404(a) requirement was extended to firms with public float less than \$75 million in 2007.
} 
next section, we describe the role of internal controls in all FS audits, followed by our hypothesis development as to how integrated audits may lead to differential overall FS audit quality.

\section{The Role of Internal Controls in Financial Statement Audits}

The output of the FS audit is an opinion on whether the financial statements are free from material misstatement. FS audits are performed using a risk-based approach, commonly operationalized with the following audit risk model:

$$
\text { Audit Risk }(A R)=\text { Inherent Risk }(I R) * \text { Control Risk }(C R) * \text { Detection Risk }(D R)^{6}
$$

where Audit Risk (AR) - the risk of audit failure - is the risk the auditor issues an unqualified audit opinion on materially misstated financial statements. Inherent Risk (IR), the risk that material misstatements occur (independent from the company's internal controls), and Control Risk (CR), the risk that the company's internal controls fail to prevent or detect material misstatements, are commonly called the Risk of Material Misstatement (AICPA 2015; COSO 2013). Thus, audit risk is a function of the auditor's assessment of the risk that pre-audit financial statements contain material misstatements (IR * CR) and the risk that the auditor's substantive procedures fail to identify existing material misstatements, or Detection Risk (DR).

Risk-based audits involve significant professional judgment in assessing risk of material misstatement and identifying sufficient and appropriate tests to achieve the desired level of audit risk. Thus, they provide ample opportunity for auditor judgment errors. FS auditors first set audit risk and estimate inherent and control risk, based on which they calculate detection risk (DR = $\mathrm{AR} /(\mathrm{IR} * \mathrm{CR}))$. Because actual inherent and control risk are uncertain, each is estimated with error based on information available during audit planning. When FS auditors wish to rely on

\footnotetext{
${ }^{6}$ While there is some debate in the literature as to the appropriate functional form of the audit risk model, we use the multiplicative function herein for ease of exposition (Akresh 2010; Kinney et al. 2013).
} 
controls over a particular assertion, and thus estimate control risk as less than its maximum, they must perform control tests to confirm their control risk estimates. If well-designed controls are operating effectively, auditors may use a combination of control and substantive testing to limit audit risk to an appropriately low level. In summary, achieving the desired level of audit risk, and ultimately FS audit quality, is a function of the auditors' ability to estimate the true state of risk of material misstatement and the quality of auditors' judgments about the nature and sufficiency of evidence required to achieve their desired level of audit risk.

\section{Hypothesis Development}

\section{Does Having an Integrated Audit Impact Financial Statement Audit Quality?}

Unlike in FS-only audits, the operating effectiveness of well-designed controls over all significant accounts and assertions must be tested for purposes of the ICFR audit. As such, integrated auditors have more information about the quality of controls when assessing control risk, which should lower audit risk estimation error relative to FS-only audits, ceteris paribus. However, at least two factors could prohibit improvements and potentially increase audit risk estimation error, thereby decreasing FS audit quality in integrated audits: (1) increased control reliance strategies in integrated audits leading to greater opportunities for judgment-based integration issues and (2) low-quality ICFR audits leading to increased control risk estimation error. We expand on these potential factors in our subsequent hypotheses. Due to competing directional predictions, we provide our first hypothesis in the null format.

H1: Financial statement audit quality does not differ between firms having audits of internal controls over financial reporting integrated with financial statement audits and similar firms having financial statement-only audits.

\section{Control Reliance and Integration Issues}

The integrated audit requirement has fundamentally altered how FS audits that are integrated with ICFR audits are performed and we broadly characterize difficulties implementing 
integrated audits as integration issues. We first discuss the shift towards greater control reliance in integrated audits. We then discuss how this shift provides increased opportunities for auditor judgment-related integration issues.

The integrated audit requirement has altered control reliance decisions such that integrated auditors rely on controls over more accounts and assertions than FS-only auditors. All auditors analyze expected costs and benefits of a substantive testing approach that includes only substantive tests to identify material misstatements, versus a continuum of control reliance strategies that include varying combinations of control and substantive testing, and choose the strategy that minimizes total effort conditional on achieving the desired level of audit risk. FSonly auditors make reliance decisions based on minimum requirements to understand internal control system design but no requirement to test operating effectiveness, which can result in primarily conducting substantive procedures. In comparison, integrated auditors make reliance decisions based on required ICFR audit testing. Thus, integrated audits can leverage control testing that has already been performed in the ICFR audit to reduce FS audit effort/costs, thereby making control reliance strategies more likely.

This fundamental change in control reliance is further amplified by client fee and auditor workload pressures. We expect integrated audits have heightened audit fee pressure (i.e., the pressure from clients to minimize fees) due to substantially higher audit fees in integrated versus FS-only audits which are particularly burdensome for small companies (Kinney and Shepardson 2011). Because costly ICFR audits must test controls, one way integrated auditors can reduce client fee pressure is by increasing control reliance to leverage ICFR audit testing. ${ }^{7}$ In addition, integrated audits have heightened workload pressure (i.e., pressure to get substantial work done

\footnotetext{
${ }^{7}$ These efficiency incentives may be further heightened if ICFR audit procedures take longer than budgeted, providing incentives to reduce substantive procedures to recoup ICFR audit losses through the FS audit.
} 
in a short period of time) due to increased requirements that need to be completed in a similar amount of time as FS-only audits (Bronson, Hogan, Johnson, and Ramesh 2011; Lopez and Peters 2012), which is of recent concern to regulators and academics (PCAOB 2012, 2013b; Buchheit, Dalton, Harp, and Hollingsworth 2016). One way to manage workload pressure is to allocate more effort to control testing that can be performed during earlier, interim testing as compared to substantive testing typically concentrated after year-end. Thus, client fee and auditor workload pressures in integrated audits serve to further increase control reliance.

Next, we posit that increased control reliance provides more opportunities for judgmentbased audit integration issues that harm FS audit quality. First, extant research finds auditors fail to appropriately adjust substantive procedures for identified risks. For example, longstanding experimental research provides systematic evidence of auditors underreacting to and insufficiently adjusting substantive procedures for identified inherent and control risks (see Allen et al. 2006 and Asare et al. 2013, respectively, for reviews). Likewise, archival studies find firms disclosing poor ICFR have low-quality financial reporting, consistent with auditors failing to appropriately adjust substantive testing even when they identify control risks (Doyle et al. 2007a; Ashbaugh-Skaife et al. 2008; Donelson, Ege, and McInnis 2017). ${ }^{8}$ In total, based on prior experimental and archival research, we expect auditors have difficulties appropriately integrating internal control conclusions into FS-audits, which harms audit quality.

Second, we posit audit timing differences between ICFR and FS auditing standards lead to misapplication of FS auditing standards in integrated audits. ICFR audit opinions are as of year-end whereas FS audit opinions are as of and for the year-ended. This timing difference can

\footnotetext{
${ }^{8}$ Consistent with under-reaction to risks, studies find results are partially mitigated with increased effort (Hogan and Wilkins 2008; Lu, Richardson, Salterio 2011; Seidel 2017; Zhao, Bedard, and Hoitash 2017).
} 
lead to inappropriate FS audit control reliance if controls are deemed effective as of year-end for the ICFR audit but are not operating effectively throughout the year (PCAOB 2013a).

In summary, we predict the shift towards increased control reliance in integrated audits increases opportunities for judgment-based integration issues, thereby impairing FS audit quality. However, because high-quality, well-integrated ICFR audits may improve FS audit quality, we present our second hypothesis in null form.

H2: Financial statement audit quality does not differ between firms having audits of internal controls over financial reporting integrated with financial statement audits and similar firms having financial statement-only audits, due to integration issues.

\section{Incremental Effects of Low-Quality ICFR Audits}

The previous hypothesis does not depend on ICFR audit quality. Next, because empirical evidence on ICFR audit quality is generally negative, we examine the incremental effect of lowquality ICFR audits on FS audit quality. Prior research finds auditors fail to identify control deficiencies or under-assess deficiency severity leading to failure to report material weaknesses (Bedard and Graham 2011; Kinney et al. 2013; Ge et al. 2017). Moreover, Rice and Weber (2012) find 68\% of firms with FS restatements do not disclose a material weakness in their initial ICFR audit opinion. More recently, Acito et al. (2015) show the 2007 change in ICFR auditing standards from Auditing Standard No. 2 to AS5 that focuses on integration and efficiency has led to even lower quality ICFR audits. Likewise, evidence on ICFR audit quality from PCAOB inspections is concerning. The PCAOB reports that in 22\% of 2011 inspected audits for large firms, auditors "failed to obtain sufficient appropriate evidence to support its opinion on the effectiveness of [ICFR]" (PCAOB 2012, 4) and the PCAOB identifies "ICFR audit-related deficiencies” as one of the three most frequent inspection findings in 2013 and 2014 inspections 
(PCAOB 2015). In summary, empirical and anecdotal evidence suggests many ICFR audits are low-quality which we posit has implications for integrated FS audit quality. ${ }^{9}$

Specifically, we expect low-quality ICFR conclusions increase control risk estimation error, which mathematically affects auditors' detection risk and thus the nature, extent, and timing of substantive procedures. For example, when auditors fail to identify an existing material weakness, control risk is under-stated, resulting in auditors performing inappropriate or insufficient substantive procedures to identify material misstatements. Thus, when integrated audits increase control risk estimation error due to low-quality ICFR audit conclusions, FS audit quality also decreases, with effects amplified by increased control reliance.

Furthermore, psychology theory and prior research suggest prior involvement influences subsequent evaluations, such that individuals are unintentionally biased to avoid finding fault with their prior work to protect their ego and self-identity (Staw 1976, 1981; Kunda 1990; Church 1991; Tan 1995; Hatfield et al. 2011). Accordingly, we expect integrated auditors who previously concluded ICFR was operating effectively (i.e., the risk of material misstatement is not reasonably possible) may be less likely to require adjustment for errors identified during substantive procedures to avoid finding fault with their prior ICFR conclusions.

Thus, we predict an incremental effect of low-quality ICFR audits on FS audit quality:

H3: Incremental to integration issues, financial statement audit quality of firms having low-quality internal controls over financial reporting audit conclusions integrated with financial statement audits is lower than for similar firms having financial statement-only audits.

\footnotetext{
${ }^{9}$ While the reasons for low-quality ICFR audits are unknown, we identify three potential contributing factors: managers' understated control deficiency conclusions (Bedard and Graham 2011; Earley, Hoffman, and Joe 2008); improper application of the top-down ICFR audit approach (PCAOB 2012); and, increased social and economic dependence on clients and/or heightened incentives to leverage controls unintentionally impairs integrated auditor objectivity in a manner that favors concluding controls are effective (e.g., Bazerman, Loewenstein, and Moore 2002; Church, Jenkins, McCracken, Roush, and Stanley 2015).
} 


\section{RESEARCH METHOD AND SAMPLE SELECTION}

\section{Integrated Audit Independent Measures}

To examine our first hypothesis, we estimate differences in three audit quality proxies between small firms with integrated audits (INTEGRATED equal to 1) and non-accelerated filers with FS-only audits (INTEGRATED equal to 0) from 2007 - 2013. ${ }^{10}$ We restrict market value of equity to less than $\$ 150$ million to improve comparability (Nagy 2010), ${ }^{11}$ and limit to post-2007 to eliminate the prior auditing standards regime (2004 - 2006) and to limit to periods when nonaccelerated filers provide SOX 404(a) management assessments of ICFR. ${ }^{12}$ To test H2 and H3, we estimate ICFR disclosure quality by separating firms into groups based on likely and disclosed high- or low-quality ICFR, as shown in Figure 1, allowing us to estimate (1) the lowquality ICFR audit effect in primary analyses and (2) whether integrated audits are associated with lower FS audit quality within firms having similar likely and disclosed ICFR quality.

\section{INSERT FIGURE 1}

To estimate ICFR disclosure quality, we use fourth quarter SOX Section 302 certifications, 404(a) management assessments, and 404(b) audit reports to determine if a material weakness was disclosed. We then estimate whether it is likely a material weakness exists. If we estimate it is likely at least one material weakness exists (does not exist) and one is (is not) reported, ICAQ_H is set equal to 1 , and 0 otherwise. These two groups are estimated to have high-quality ICFR disclosures. If we estimate it is likely at least one material weakness

\footnotetext{
${ }^{10}$ Our sample includes voluntary compliers; Ge, Koester, and McVay (2017) identify 273 voluntarily compliers. . If they do so because they have higher quality ICFR, voluntary compliance should bias against our results.

${ }^{11}$ Accelerated filer classifications are based on public float, common equity held by non-affiliates. In 2015, for firms with less than \$250 million in market capitalization, mean market value of equity (public float) is \$111.1 million (\$50.0 million) (SEC 2016). Thus, it is reasonable to limit accelerated filers to firms with less than $\$ 150$ million in market capitalization, as they are similar, from a market value of equity perspective, to non-accelerated filers.

${ }^{12}$ When we reperform our main analyses including 2005 and 2006, we find qualitatively similar results to those reported in Tables 4 and 6 with the exception of ICAQ_L2 (test of H3) in the discretionary accrual results, which is no longer significant.
} 
exists (does not exist) and one is not disclosed (is disclosed), we set ICAQ_L2 (ICAQ_L1) equal to 1, 0 otherwise. ICAQ_L2 represents low-quality, Type II errors (i.e., under-assessments of CR) and is used in our hypothesis tests. ${ }^{13}$

To estimate the likelihood at least one material weakness exists, we use a logistic regression model, adapted from prior studies (Ashbaugh-Skaife, Collins, and Kinney 2007; Doyle et al. 2007b; Acito et al. 2015; Ge et al. 2017). We estimate the model in-sample, by year for firm-year observations in Audit Analytics and Compustat with market value of equity less than $\$ 150$ million and identify cut-off probabilities of material weakness that maximize the rate of correct classification (Hosmer and Lemeshow 2000). ${ }^{14}$ Firm-year specific probabilities above (below) the cut-off indicate the firm-year is likely to have (not have) at least one material weakness in ICFR. We compare our expectation to disclosures to classify observations into disclosure quality groups. Variable definitions can be found in the Appendix. The model is:

$$
\begin{aligned}
& M W_{i, t}=\beta_{0}+\beta_{1} L_{N M V E_{i, t}}+\beta_{2} L N A G E_{i, t}+\beta_{3} L N B S E G_{i, t}+\beta_{4} \text { FOREIGN }_{i, t}+ \\
& \beta_{5} M \& A_{i, t}+\beta_{6} \text { RESTRUCTURE }_{i, t}+\beta_{7} \text { ARINV }_{i, t}+\beta_{8} \text { AGROWTH }_{i, t}+ \\
& \beta_{9} C F O_{i, t}+\beta_{10} L_{O S S_{i, t}}+\beta_{11} M B R_{i, t}+\beta_{12} L I T_{i, t}+\beta_{13} B I G N_{i, t}+ \\
& \beta_{14} A U D \_R E S I G N_{i, t}+\beta_{15} A N C \_R S T_{i, t}+\beta_{16} P Y \_M W_{i, t}+ \\
& \beta_{17 \text { INTEGRATED }}, \mathrm{it}+\text { Industry Fixed Effects }+\varepsilon_{\mathrm{i}, \mathrm{t}}
\end{aligned}
$$

The dependent variable $(M W)$ takes the value of 1 if at least one material weakness is reported, 0 otherwise. We include firm-specific factors found in prior research to be associated with internal control quality including natural logs of market value of equity (LNMVE), firm age (LNAGE), the natural log of business segments (LNBSEG), and whether the company has foreign operations (FOREIGN). We include measures of whether the company underwent a merger

\footnotetext{
${ }^{13}$ ICAQ_L1 represents expected low-quality ICFR disclosures due to Type I ICFR disclosure errors, which will result in over-assessment of control risk. While we examine this subgroup for completeness, we note it is not included in our test of H3 because it is inconsistent with under-estimating control risk.

${ }^{14}$ We pool small accelerated and non-accelerated filers and estimate by year because estimating by year reduces potential bias due to fluctuating macroeconomic conditions and pooling across filer status increases predictive power by increasing observations with disclosed material weaknesses.
} 
$(M \& A)$ or restructuring (RESTRUCTURE), accounts receivable and inventory scaled by assets (ARINV), and year-over-year asset growth (AGROWTH). Finally, we include a measure of operating cash flows (CFO), whether the company experiences a loss (LOSS), the market-tobook ratio $(M B R)$, and an indicator if the firm is in a high litigation industry (LIT).

As larger audit firms have more resources and greater incentives to detect and disclose material weaknesses, we include a measure of auditor size (BIGN). Prior year auditor resignations (AUD_RESIGN) and current year announced restatements (ANC_RST) may indicate the firm has poor ICFR. Because low-quality ICFR tends to persist, we include an indicator of prior year material weakness (PY_MW). We include INTEGRATED as disclosure rates for ICFR audits and management assessments differ. Finally, we include industry fixed-effects.

Table 1 provides estimated cut-off probabilities by year, fit statistics, and results of the 2007 estimation. The area under the Receiver Operating Characteristic (ROC) curve statistics are greater than .78 , indicating acceptable discrimination of our model. ${ }^{15}$

\section{INSERT TABLE 1}

In addition to our in-sample estimation method, we estimate ICFR disclosure quality using two out-of-sample methods. First, we use a K-fold method using ten randomly assigned hold-out validation samples (i.e., Larcker and Zakolykina 2012). We hold out each validation sample iteratively and estimate Equation (1), including year fixed-effects, on the remaining 90\% of observations (the training samples), calculate the predicted probability for each validation observation, and classify validation observations into ICFR disclosure quality groups based on coefficients and cutoff probabilities estimated in the training samples. Second, we calculate predicted probabilities of material weakness using Equation (2) in Ge et al. (2017), obtained from

\footnotetext{
${ }^{15}$ There are insignificant covariates in the annual expectations models. We re-estimate the models only including those that are statistically significant and find qualitatively similar results to those reported in Tables 4 - 7 .
} 
regressing accelerated filer material weakness disclosures in 2004 - 2006 on a subset of predictor variables used in Equation (1). Consistent with Ge et al. (2017), we consider firm-years in the top quintile of predicted probability as having a likely material weakness in ICFR and compare our expectation to disclosures to classify firms in ICFR disclosure quality groups. When using these out-of-sample estimates to perform our primary H2 and H3 tests, we find consistent results.

\section{INSERT TABLE 1}

\section{Financial Statement Audit Quality Measures and Models}

We measure FS audit quality using three measures from prior research (Knechel, Krishnan, Pevzner, Shefchik, and Velury 2013; Choudhary, Merkley, and Schipper 2017): (1) the likelihood financial statements contain a material misstatement that leads to a future restatement (2) the likelihood financial statements contain a misstatement, whether or not disclosed as material, that leads to a future restatement, and (3) absolute value of discretionary working capital accruals. The issuance of materially misstated financial statements is most indicative of audit failure. While misstatements are a less precise audit failure measure, we include it because it encompasses a larger set of misstatements. We also use discretionary accruals as a continuous measure of FS audit quality because it does not suffer from detection effect concerns present when future revelation of errors is required for identification.

MAT_MISSTATE equals 1 if current year FS contain a material misstatement that is restated in a future period, 0 otherwise. We identify subsequently restated years and classify those for which an Item 4.02 8-K, required when previously issued financial statements should no longer be relied upon due to material misstatements (SEC 2006), is filed with the SEC. MISSTATE equals 1 if current year FS are restated in the future, regardless of materiality, 0 otherwise and thus captures additional restatements that might be considered material by a 
reasonable user. $A B S D C A C C$ is the absolute value of firm-year residuals obtained from a regression of working capital accruals using a modified Jones model that controls for performance, growth, lagged accruals, and non-linear effects of positive and negative cash flows from operations, estimated for each industry-year with at least 20 observations. ${ }^{16}$

\section{Misstatement Model}

Following is the logistic regression that predicts the likelihood of material misstatements and misstatements of current year audited FS with variable definitions found in the Appendix.

$$
\begin{aligned}
& \text { MAT_MISSTATE } / \quad \beta_{0}+\beta_{1} \text { INTEGRATED }_{i, t}+\beta_{2} \text { LNASSETS }_{i, t}+\beta_{3} \text { LOSS }_{i, t}+\beta_{4} R O A_{i, t}+ \\
& \text { MISSTATE }_{i, t}=\beta_{5} \text { FNDSRSED }_{i, t}+\beta_{6} M_{i, t}+\beta_{7} \text { BKMKT }_{i, t}+\beta_{8} Q R A T I O_{i, t}+ \\
& \beta_{9} I I N T C O V_{i, t}+\beta_{10} L E V_{i, t}+\beta_{11} L N F E E_{i, t}+\beta_{12} M W_{i, t}+ \\
& \beta_{13} A N C \_R S T_{i, t}+\beta_{14} I_{N S T P C T} T_{i, t}+\beta_{15} B L K P C T_{i, t}+ \\
& \beta_{16} A G R O W T H_{i, t}+\beta_{17} P Y S T K R E T_{i, t}+\text { Auditor Fixed Effects }+ \text { Year } \\
& \text { Fixed Effects }+ \text { Industry Fixed Effects }+\varepsilon_{\mathrm{i}, \mathrm{t}}
\end{aligned}
$$

INTEGRATED is the variable of interest for testing H1; a positive (negative) coefficient indicates firms receiving integrated audits have a higher (lower) likelihood of misstatement, consistent with lower (higher) FS audit quality. We re-estimate Equation (2) including an indicator for firm-years we estimate have ICFR audits with undisclosed material weaknesses, ICAQ_L2, addressing whether systematic integration issues (H2) and incremental effects of lowquality ICFR audits (H3) are both present. Additionally, we re-estimate Equation (2) within each comparison group of high- and low-quality ICFR disclosures.

We begin by including control variables shown in prior research to predict misstatements (Palmrose and Scholz 2004; Scholz 2008; Efendi, Srivastava, and Swanson 2007; Blankely, Hurtt, and MacGregor 2012). We include LNASSETS to control for firm size, LOSS and ROA to control for performance, and measures of the need for financing (FNDSRSED) and M\&A. We include the book-to-market ratio $(B K M K T)$ to control for growth. We also include the quick ratio

\footnotetext{
${ }^{16}$ We discuss the sensitivity of our results to this choice in Section V.
} 
(QRATIO), inverse interest coverage ratio (IINTCOV), and ratio of liabilities to assets (LEV) to control for debt covenant pressure and leverage. We include LNFEE as increased fees should reduce resource pressure (Hogan and Wilkins 2008; Lu et al. 2011; Seidel 2016; Zhao et al. 2017). In full sample regressions, we include $M W$ and $A N C \_R S T$ as evidence suggests restating firms are likely to restate again (Files, Sharp, and Thompson 2014).

We next include several factors associated with public float, which determines INTEGRATED status, because prior research finds that firms manipulate public float to avoid ICFR audits (Gao et al. 2009; Iliev 2010) and factors related to float selection could be correlated with INTEGRATED and FS audit quality. ${ }^{17}$ We include the percentage of market value of equity held by institutions (INSTPCT) and large blockholders (BLKPCT) as each may be beneficial to monitoring. AGROWTH and PYSTKRET, lagged annual stock return, are measures of growth and performance and should be associated with float. We include auditor fixed-effects, to control for audit methodology differences, and year and industry fixed-effects. ${ }^{18}$

\section{Discretionary Accruals Model}

Below is the model using discretionary accruals as our audit quality measure, with variable definitions found in the Appendix.

$$
\begin{aligned}
& \beta_{0}+\beta_{1} \text { INTEGRATED }_{i, t}+\beta_{2} \text { LNASSETS }_{i, t}+\beta_{3} \text { PYTACC }_{i, t}+\beta_{4} \text { CFO }_{i, t}+ \\
& A B S D C A C C_{i, t}=\beta_{5} L_{O S S}{ }_{i, t}+\beta_{6} S T D \_S A L E S_{i, t}+\beta_{7} S T D \_C F O_{i, t}+\beta_{8} S G R O W T H_{i, t}+ \\
& \beta_{9} \text { PPEGROWTH } H_{i, t}+\beta_{10} B K M K T_{i, t}+\beta_{11} L E V_{i, t}+\beta_{12} Z_{10 I J}{ }_{2} S H U M_{i, t}+ \\
& \beta_{13} L_{\text {NBSEG }}{ }_{i, t}+\beta_{14} \text { FOREIGN }_{i, t}+\beta_{15} \text { STKRET }_{i, t}+\beta_{16} L I T_{i, t}+\beta_{17} M W_{i, t}+ \\
& \beta_{18} \text { INSTPCT }_{i, t}+\beta_{19} B L K P C T_{i, t}+\beta_{20} \text { AGROWTH }_{i, t}+{ }_{21} P_{P S T K R E T}{ }_{i, t}+ \\
& \text { Auditor Fixed Effects + Year Fixed Effects + Industry Fixed Effects + } \\
& \varepsilon_{\mathrm{i}, \mathrm{t}}
\end{aligned}
$$

\footnotetext{
${ }^{17}$ In sensitivity analyses, we directly include public float, as well as its squared and cubic terms, to control for nonlinear effects (Gao et al. 2009; Iliev 2010). In addition, we exclude those firms most likely to be manipulating their float to avoid ICFR audits. Results remain economically and statistically similar.

${ }^{18}$ We re-estimate our analyses replacing auditor fixed-effects with BigN and find qualitatively similar results to primary analyses. We also interact $B i g N$ with our independent variables to assess whether any identified effects of integrated audits are moderated by BigN (higher quality) auditors, and find no evidence of moderation.
} 
We include control variables shown in prior research to be associated with discretionary accruals (e.g., Hribar and Nichols 2007; Francis and Yu 2009; Choi, Kim, Kim, and Zang 2010; Reichelt and Wang 2010; Francis and Michas 2012; Defond, Erkens, and Zhang 2016). We include LNASSETS and prior year total accruals (PYTACC). We expect firms with higher CFO and losses (LOSS) have lower and higher discretionary accruals, respectively. We include standard deviation of sales (STD_SALES) and operating cash flows (STD_CFO) to control for uncertainty. We control for growth by including sales growth (SGROWTH), PPE growth (PPEGROWTH), and BKMKT. We include LEV, bankruptcy risk (ZMIJ_SHUM), and controls for complexity LNBSEG and FOREIGN. We include annual stock return (STKRET), litigation risk (LIT), MW and variables likely associated with INTEGRATED and accruals (INSTPCT, BLKPCT, AGROWTH, and PYSTKRET) as well as auditor, industry, and year fixed-effects.

\section{Sample Selection}

We begin our sample in 2007 to constrain to (1) the current auditing standards regime and (2) the period when all firms provide management's assessment of ICFR under SOX 404(a) and end in 2013 as we require at least two subsequent years for revelation of future restatements. We begin with 18,839 observations representing the intersection of Compustat North America and Audit Analytics for U.S. public companies with market value of equity less than or equal to $\$ 150$ million. ${ }^{19}$ We eliminate 4,170 financial institution observations (SIC codes 6000-6999) and $5,604(6,692)$ observations due to missing data necessary to calculate variables for misstatement (accruals) models. In addition to regulatory environment-driven differences of financial institutions, their exclusion is important because those with over $\$ 500$ million in total assets have

\footnotetext{
${ }^{19}$ When we increase the market value of equity cutoff to $\$ 300$ million, consistent with Kinney and Shepardson (2011) and Ge et al. (2017), as well as increase the minimum market value of equity to $\$ 5$ million, results are qualitatively similar.
} 
annual attestations of internal controls to comply with regulatory requirements beginning in 1992 (FDICIA 1991). Thus, public issuer integrated auditing requirements are likely less meaningful for these firms and their auditors. This results in a final sample of 9,065 and 7,977 observations for the misstatement and discretionary accruals analyses, respectively.

\section{INSERT TABLE 2}

\section{RESULTS}

\section{Descriptive Statistics and Univariate Results}

Panel A of Table 3 provides descriptive statistics for firm-years in the misstatement samples. Firms with integrated audits are more likely to issue materially misstated (misstated) financial statements compared to FS-only audits: 4.6 vs. 3.3 percent (9.9 vs. 6.8 percent), respectively. Panel B provides descriptive statistics for the discretionary accruals sample and shows $A B S D C A C C$ is lower for integrated audit firm-years. Panel C provides dependent measure comparisons for the four groups discussed in Figure 1 and shows restatement rates are higher for firm-years with integrated audits. A small number of observations are classified as expected lowquality ICFR disclosures where a material weaknesses is not likely but at least one is disclosed (approximately 4 percent). Because this group is likely an artifact of MW prediction model estimation error, we do not include this group to test our low-quality ICFR audit hypothesis.

\section{INSERT TABLE 3}

\section{Multivariate Results}

\section{Misstatement Results}

Table 4 presents logistic regression results where FS audit quality is measured as the likelihood current period financial statements contain a material misstatement (Columns (1) and (2)) or a misstatement (Columns (3) and (4)). Columns (1) and (3) provide comparisons of 
integrated vs. FS-only audits to test H1 and Columns (2) and (4) separate systematic integration issues (H2) and the incremental effect of low-quality ICFR audits (H3).

\section{INSERT TABLE 4}

In Columns (1) and (3), the coefficients on INTEGRATED are positive and significant, indicating a higher likelihood of material misstatements and misstatements for integrated audits relative to similar firm-years with FS-only audits. Thus, in tests of H1, we find integrated audits are associated with lower FS audit quality. The marginal effect of having an integrated audit is 0.023 , or $85.8 \%$, for material misstatements and 0.018 , or $68.9 \%$, for misstatements. ${ }^{20}$

Next, in Columns (2) and (4), we find positive and significant coefficients on INTEGRATED and ICAQ_L2, consistent with H2 and H3. That is, we find lower FS audit quality in firm-years with integrated relative to FS-only audits while controlling for low-quality ICFR audits, consistent with judgment-based integration issues (H2). We also find incremental lowquality ICFR audit effects (H3). When controlling for low-quality ICFR audits, the marginal effect of an integrated audit is 0.018 , or $68.9 \%$, for material misstatements and 0.027 , or $40.7 \%$, for misstatements. Low-quality ICFR audits represent an additional increase of 0.029, or $112.7 \%$, for material misstatements and 0.039 , or $57.8 \%$, for misstatements.

Table 5 presents results for each of the four ICFR disclosure quality groups for the material misstatements (Panel A) and misstatements (Panel B) analysis, and provides better comparisons between firm-years having integrated and FS-only audits than cross-sectional analyses which calculate statistical significance as compared to the average FS-only audit. Related to H1, material misstatement and misstatement results support that FS audit quality is

\footnotetext{
${ }^{20}$ We calculate marginal effects by subtracting predicted probabilities of misstatement when the independent variable of interest equals zero from predicted probabilities when independent variables equal one, holding control variables constant at their means. Percentages reported are calculated as marginal effects scaled by conditional probabilities of material misstatement or misstatement with all variables equal to their means.
} 
lower for firm-years with integrated audits in all four groups (the effect is marginally significant where we estimate at least one material weakness exists and one is disclosed).

\section{INSERT TABLE 5}

Related to H2, addressing whether coefficients on INTEGRATED are significant in the high-quality groups (Columns (1) and (2)) eliminates concerns that H1 results are due entirely to low-quality ICFR audits. Within the high-quality, material weakness group (Columns (1)), results for both misstatement analyses are marginally significant and support H2. Within the high-quality, no material weakness group (Columns (2)), results for both misstatement analyses support H2; the marginal effect of having an integrated audit is 0.011 , or $127.6 \%$, for material misstatements and 0.025 , or $89.36 \%$, for misstatements. Finally, within the low-quality ICFR disclosure group (Columns (3)) the marginal effect of having an integrated audit is 0.064 , or $116.9 \%$, for material misstatements and 0.077 , or $56.7 \%$, for misstatements.

\section{Discretionary Accruals Results}

Table 6 presents OLS regression results using discretionary working capital accruals. The coefficient on INTEGRATED is positive and significant in Column (1), consistent with H1. As shown in Column (2), we find positive and significant coefficients on INTEGRATED and ICAQ_L2, consistent with lower FS audit quality due to integration issues (H2) and incremental effects for low-quality ICFR audits (H3).

\section{INSERT TABLE 6}

Table 7 presents results of discretionary accruals regressions for the four ICFR disclosure quality groups. The coefficient on INTEGRATED is significant for the high-quality, no material weakness disclosure group (Column (2)), supporting systematic integration issues. However, INTEGRATED is not significant for the high-quality, material weakness disclosure group 
(Column (1)). The coefficient on INTEGRATED is positive and marginally significant $(\mathrm{p}=$ 0.061) for the low-quality ICFR disclosures group (Column (3)).

\section{INSERT TABLE 7}

Overall, results of analyses using material misstatements, misstatements, and discretionary accruals as FS audit quality proxies provide strong evidence that integrated audits are associated with worse FS audit quality than similar firms with FS-only audits, regardless of ICFR audit quality. The evidence is consistent with judgment-based integration issues and amplified effects of low-quality ICFR audits each affecting FS audit quality such that auditors fail to perform adequate substantive procedures to identify material misstatements.

\section{ADDITIONAL AND SENSITIVITY ANALYSES}

\section{Additional Analyses}

\section{Integrated Audit Detection of Misstatements}

An alternative explanation for our misstatement results is that integrated auditor control deficiency detection leads to detection of prior period misstatements. We address why our pattern of results is inconsistent with a detection effect in four ways.

First, for this alternative to have merit, integrated audits must identify either more control deficiencies or restatements of prior periods when deficiencies are identified. When we estimate whether firm-years with integrated audits are more likely to disclose a SOX 302 material weakness using the same control variables from Equation (1), we find an insignificant coefficient on INTEGRATED (coef. $=-0.0439$; z-stat $=-0.47$ ) ${ }^{21}$ Next, when we estimate whether announced restatements are more likely for integrated audits of the firm-years disclosing SOX 302 material weaknesses, using all control variables from Equation (2), we find announced restatements are

\footnotetext{
${ }^{21}$ We use SOX 302 material weaknesses to include all material weaknesses disclosed during the year. Using only SOX 404(b) material weakness disclosures will limit to only those that are unremediated as of year-end.
} 
no more likely in firm-years with integrated audits (coef. $=-0.0551$; z-stat $=-0.34$ ). In sum, we find no evidence of increased material weakness or prior period restatement detection in integrated audits. Second, we classify restatements with the greatest potential for detection effects as those announced in a quarter in which a material weakness was disclosed and assume material weakness identification led to misstatement detection in all cases. Of restatements announced in firm-years having integrated audits, only 37\% exhibit potential detection effects, as compared to $43 \%$ with FS-only audits, contrary to an integrated audit detection effect.

Third, if integrated audits are more likely to identify prior period misstatements, we would expect a higher misstatement likelihood than observed in the 2001 - 2003 period for firmyears having integrated audits (classified by whether they had an integrated audit in 2004) as 2001 - 2003 misstatements would likely be identified via post-2003 integrated audits. In later sensitivity analysis (Table 9), we do not find evidence consistent with this conjecture. Finally, if results are due to a detection effect, we would not expect to find consistent results using discretionary accruals for which results are not conditional on future detection of errors.

\section{Self-Selection of Public Float and Match on Public Float Determinants}

Extant research concludes some firms avoid integrated audits by taking actions to maintain public float under $\$ 75$ million (Gao et al. 2009; Iliev 2010). If firms self-selecting FSonly audits do so because they correctly conclude compliance is net costly, then including firmyears in which managers intentionally avoid integrated audits could bias towards our findings. To address this concern, we obtain public float from the cover of 10-K filings when available (n $=8,568$ and 7,411 for the misstatement and discretionary accruals sample, respectively). We define 136 (123) firm-years for the misstatement and discretionary accruals sample, respectively, with FS-only audits and public float as of their second fiscal quarter between \$65 and \$75 
million as potential evaders, consistent with Gao et al. (2009) and Iliev (2010). Table 8 presents primary results using firms with disclosed public float (Panel A) and eliminating potential evaders (Panel B). Results are consistent with our primary results.

\section{INSERT TABLE 8}

To further address float selection concerns, we construct a propensity score matched sample where we perform a 1-to-1, without replacement match of integrated and FS-only observations based on the four public float determinants discussed in Section 3, industry, and year resulting in a sample size of 4,202 (4,022) observations for misstatement (discretionary accruals) analyses. ${ }^{22}$ Panel C of Table 8 shows differences in means for the public float determinants are not significant and results in Panel $\mathrm{D}$ are consistent with primary results.

\section{Differences in Pre- and Post-Integrated Audit Periods}

To further reduce concerns our results are due to differences in firm characteristics, we compare regression coefficients from our primary tests to coefficients estimated in the pre-SOX 404 period when all firms received FS-only audits, using seemingly unrelated estimation. We use the presence or absence of an ICFR audit opinion in 2004 to classify observations as integrated vs. FS-only in the pre-period, 2001 to 2003. As presented in Table 9, the coefficients on INTEGRATED for the 2001 to 2003 results (Column 1) are not significant for any of the three FS audit quality measures (Panels A to C), suggesting firms had similar FS audit quality prior to integrated audits, consistent with integrated audits inducing FS audit quality differences. Crossmodel comparisons are positive and significant (Column 3) for all three FS audit quality measures, consistent with FS audit quality significantly declining for integrated relative to FSonly audits from the pre- to post-integrated audit periods.

\footnotetext{
22 To ensure sufficient overlap between treatment and control observations, we expand our population to all observations with market value of equity less than $\$ 400$ million.
} 


\section{INSERT TABLE 9}

\section{Switching from FS-Only to Integrated Audits}

We re-estimate Columns (2) and (4) from Table 4 and Column (2) from Table 6 using a sample in which firms switched from FS-only to integrated audits. Similar in spirit to the Pre/Post- analysis previously discussed, this analysis identifies whether effects exist within firms experiencing a change from FS-only to integrated audits. We compare the years before and after the switch to determine if FS audit quality declines. Despite a limited sample size $(n=529$ for the misstatement analyses), we find (untabulated) firms that switch from FS-only to integrated audits have increased likelihoods of material misstatement (misstatement) consistent with integration difficulties affecting FS audit quality (coef. = 1.1238 (0.9489); z-stat = 2.50 (2.59)), and an insignificant incremental effect of low-quality ICFR audits. Results are insignificant for the discretionary accruals analysis, however, the sample is small $(\mathrm{n}=515)$.

\section{Differences in Pre vs. Post-PCAOB ICFR Audit Inspection Scrutiny}

PCAOB inspections began scrutinizing ICFR audits in 2010, which DeFond and Lennox (2017) conclude led to improved ICFR audit quality. DeFond and Lennox (2017) do not, however, address whether FS audit quality improved post ICFR audit inspections. We partition our sample into pre- and post-ICFR audit inspection scrutiny periods (2007 to 2010 and 2011 to 2013) and re-estimate Tables 4 and 6 using seemingly unrelated estimation (untabulated).

In reperformance of $\mathrm{H} 1$ tests, we find significant coefficients on INTEGRATED using all three audit quality measures from 2007 to $2010 .^{23}$ For 2011 to 2013, we find a significant coefficient on INTEGRATED in the discretionary accruals model (coef. =0.0459; t-statistic $=$

\footnotetext{
${ }^{23}$ Specifically, we find coefficient $=0.8539(\mathrm{z}$-statistic $=4.30)$ using material misstatements, coefficient $=0.5923$ $(\mathrm{z}$-statistic $=3.45)$ using misstatements and coefficient $=0.0308$ (t-statistic $=3.81)$ using discretionary accruals.
} 
4.40) and marginally significant for the misstatement model (coefficient $=0.4070$; z-statistic $=$ 1.65). However, the coefficient on INTEGRATED for the material misstatement model is insignificant $($ coefficient $=0.6109$; $\mathrm{z}$-statistic $=1.49$ ). When we estimate differences in coefficients on INTEGRATED and ICAQ_L2 between the pre- and post-scrutiny periods using all three audit quality proxies, we identify one marginally significant cross-model difference in coefficients on ICAQ_L2 (Chi-Square = 3.30) using the MAT_MISSTATE specification. In summary, we find evidence that FS-audit quality is lower for integrated relative to FS-only audits even with heightened inspection scrutiny, although results partially support that incremental effects of low-quality ICFR audits have diminished with PCAOB scrutiny.

\section{Sensitivity of Results to Discretionary Accruals Estimation}

Primary analyses use absolute values of discretionary accruals, which treat both income increasing and decreasing deviations as evidence of lower FS audit quality. However, income decreasing accruals could deviate from expectation due to events such as discontinued operations and restructurings. We therefore re-estimate our analyses using signed, income increasing, and decreasing accruals. Using signed accruals, we find results consistent with primary analyses except we do not find results consistent with H3. We find results consistent with our primary analyses using the income increasing subsample and insignificant coefficients using the income decreasing subsample. Results help mitigate concerns that our discretionary accruals results are due to factors other than poor FS audit quality.

We use a working capital-based discretionary accruals estimate that controls for performance, growth, and prior year accruals in the first-stage model used in recent ICFR audit research (Schroeder and Shepardson 2016). To test the robustness of our results to additional methods, we follow an approach similar to Dechow, Hutton, Kim, and Sloan (2012) and estimate 
four iterations of discretionary accruals each using working capital (i.e., net income plus depreciation less operating cash flows) and total accruals (i.e., net income less operating cash flows) as the first-stage dependent variable, using determinants consistent with: i) Jones (Jones 1991); ii) Modified Jones (Dechow, Sloan, and Sweeney 1995); iii) McNichols (McNichols 2002); and iv) Modified Jones controlling for performance in the first stage (Kothari, Leone, and Wasley 2005). Finally, we estimate two additional working capital accruals measures consistent with Collins, Pungaliya, and Vijh (2017) and Dechow and Dichev (2002). We find results (untabulated) consistent with our primary analyses for $\mathrm{H} 1$ and $\mathrm{H} 2$ using all specifications of discretionary accruals. Regarding the incremental effect of low-quality ICFR audits (H3), we find significant results using four of six additional working capital-based discretionary accruals estimates but do not find results consistent with H3 when using total accruals-based estimates.

\section{Research Design Limitation}

To provide suitable comparisons to firms with FS-only audits, we analyze small firms. However, because all FS auditors use the audit risk model and opportunities for judgment errors exist in all integrated audits, results should be important for all integrated auditors. In addition, small issuer results are important because (1) audits are disproportionately costly for small firms, thus any additional costs imposed on this group are detrimental and (2) reporting quality effects may be most important in small firms where information asymmetry is highest.

\section{CONCLUSION}

In this study, we address what we believe is an essential question to understanding costs of integrated audits: does the integration of an audit of internal controls over financial reporting with a financial statement audit affect financial statement audit quality? Using a sample of small firms from 2007 - 2013, we find integrated audits are associated with lower FS audit quality than 
similar FS-only audits and results are consistent with both systematic judgment-based integration issues and low-quality ICFR audits impairing financial statement audit quality. These findings have important implications for the PCAOB, as the standard setter for U.S. public company audits, the SEC, as they continue consideration of costs and benefits of the ICFR audit exemption, and auditors, as they address how to obtain high-quality integrated audit outcomes. Our finding that FS audit quality is lower in integrated audits even in the case of high-quality ICFR audits, suggests changes in auditing standards aimed solely at improving the quality of ICFR audits would not be sufficient. Auditors and the PCAOB also should consider how to better integrate control-related information into financial statement audits to achieve better overall integrated audit quality. 


\section{REFERENCES}

Acito, A., C. Hogan, and A. Imdieke. 2015. Integrated Auditing Standards and Financial Reporting Quality. Working paper, Michigan State University.

Akresh, A. 2010. A Risk Model to Opine on Internal Control. Accounting Horizons 24: 65-78.

Allen, R., D. Hermanson, T. Kozloski, and R. Ramsay. 2006. Auditor Risk Assessment: Insights from the Academic Literature. Accounting Horizons 20: 157-177.

American Institute of Certified Public Accountants (AICPA). 2015. Materiality in Planning and Performing an Audit.

Asare, S., B. Fitzgerald, L. Graham, J. Joe, E. Negangard, and C. Wolfe. 2013. Auditors’ Internal Control over Financial Reporting Decisions: Analysis, Synthesis, and Research Directions. Auditing: A Journal of Practice \& Theory 32: 131-166.

Ashbaugh-Skaife, H., D. Collins, and W. Kinney. 2007. The Discovery and Reporting of Internal Control Deficiencies Prior to SOX-Mandated Audits. Journal of Accounting and Economics 44: 166-192.

Ashbaugh-Skaife, H., D. Collins, W. Kinney, and R. Lafond. 2008. The Effect of SOX Internal Control Deficiencies and Their Remediation on Accrual Quality. The Accounting Review 83: 217-50.

Bazerman, M. H., Loewenstein, G., \& Moore, D. A. 2002. Why good accountants do bad audits. Harvard business review 80: 96-103.

Bedard, J., and L. Graham. 2011. Detection and Severity Classifications of Sarbanes-Oxley Section 404 Internal Control Deficiencies. The Accounting Review 86: 825-855.

Blankley, A., D. Hurtt, and J. MacGregor. 2012. Abnormal audit fees and restatements. Auditing: A Journal of Practice and Theory 31: 79-96.

Boland, C., Bronson, S., and Hogan, C. 2015. Accelerated Filing Deadlines, Internal Controls, and Financial Statement Quality: The Case of Originating Misstatements. Accounting Horizons 29: 551-575.

Bronson, S. N., Hogan, C. E., Johnson, M. F., \& Ramesh, K. 2011. The unintended consequences of PCAOB auditing Standard Nos. 2 and 3 on the reliability of preliminary earnings releases. Journal of Accounting and Economics 51: 95-114.

Buchheit, S., D. W. Dalton, N. L. Harp, C. Hollingsworth. 2016. A Contemporary Analysis of Accounting Professionals’ Work-Life Balance. Accounting Horizons 30: 41-62.

Choi, J. - H., C. Kim, J - B. Kim, and Y. Zang. 2010. Audit Office Size, Audit Quality, and Audit Pricing. Auditing: A Journal of Practice \& Theory 29: 73-97. 
Choudhary, K., J. Merkley, and K. Schipper. 2017. Qualitative Characteristics of Financial Reporting Errors Deemed Immaterial by Managers. Working paper, Georgetown University, Cornell University, and Duke University.

Church, B. K. 1991. An examination of the effect that commitment to a hypothesis has on auditors' evaluations of confirming and disconfirming evidence. Contemporary Accounting Research 7 (Spring): 513-534.

Church, B. K., G. Jenkins, S. A. McCracken, P. B. Roush, and J. D. Stanley. 2015. Auditor independence in fact: Research, regulatory, and practice implications drawn from experimental and archival research. Accounting Horizons 29 (1): 217-238.

Collins, D. W., R. S. Pungaliya, and A. M. Vijh. 2017. The Effects of Firm Growth and Model Specification Choices on Tests of Earnings Management in Quarterly Settings. The Accounting Review 92 (2): 69-100.

Committee of Sponsoring Organizations of the Treadway Commission (COSO). 2013. Internal Control - Integrated Framework. New York, NY: COSO.

Dechow, P. M., A. P. Hutton, J. H. Kim, and R. G. Sloan. 2012. Detecting Earnings Management: A New Approach. Journal of Acounting Research 50 (2): 275-334.

Dechow, P. M., and I. D. Dichev. 2002. The Quality of Accruals and Earnings: The Role of Accrual Estimation Errors. The Accounting Review 77 (Supplement): 35-59.

Dechow, P. M., R. G. Sloan, and A. P. Sweeney. 1995. Detecting Earnings Management. The Accounting Review 70: 193-225.

DeFond, M., D. Erkens, and J. Zhang. 2016. Does PSM Really Eliminate the Big N Audit Quality Effect? Management Science 63: 3628 - 3649.

DeFond, M.L. and Lennox, C.S., 2017. Do PCAOB Inspections Improve the Quality of Internal Control Audits?. Journal of Accounting Research 55 (3): 591-627.

Dhaliwal, D., V. Naiker, and F. Navissi. 2010. The Association between Accruals Quality and the Characteristics of Accounting Experts and Mix of Expertise on Audit Committees. Contemporary Accounting Research 27: 787-827.

Donelson, D. C., Ege, M. S., \& McInnis, J. M. 2017. Internal control weaknesses and financial reporting fraud. Auditing: A Journal of Practice \& Theory 36: 45-69.

Doyle, J., W. Ge, and S. McVay. 2007a. Accruals Quality and Internal Control over Financial Reporting. The Accounting Review 82: 1141-1170.

Doyle, J., W. Ge, and S. McVay. 2007b. Determinants of Weaknesses in Internal Control over Financial Reporting. Journal of Accounting and Economics 44: 193-223. 
Earley, C., V. Hoffman, and J. Joe. 2008. Reducing Management’s Influence on Auditors' Judgments: An Experimental Investigation of SOX 404 Assessments. The Accounting Review 83: 1461-1485.

Efendi, J., A. Srivastava, and E. Swanson. 2007. Why Do Corporate Managers Misstate Financial Statements? The Role of Option Compensation and Other Factors. Journal of Financial Economics 85: 667-708.

Files, R., N. Sharp, and A. Thompson. 2014. Empirical Evidence on Repeat Restatements. Accounting Horizons 28: 93-123.

Francis, J., and P. Michas. 2012. The Contagion Effect of Low-Quality Audits. The Accounting Review 88: 521-552.

Francis, J., and M. Yu. 2009. Big 4 Office Size and Audit Quality. The Accounting Review 84: 1521-1552.

Gao, F., J. S. Wu, and J. Zimmerman. 2009. Unintended Consequences of Granting Small Firms Exemptions from Securities Regulation: Evidence from the Sarbanes-Oxley Act. Journal of Accounting Research 47 (2): 459-506.

Ge, W., A. Koester, and S. McVay. 2017. Benefits and Costs of Sarbanes-Oxley Section 404(b) Exemption: Evidence from Small Firms' Internal Control Disclosures. Journal of Accounting and Economics 63 (2-3): 358-384.

Hatfield, R. C., S. B. Jackson, and S. D. Vandervelde. 2011. Effects of prior auditor involvement and client pressure on proposed audit adjustments. Behavioral Research in Accounting 23 (2): 117-130.

Hogan, C., and M. Wilkins. 2008. Evidence on the Audit Risk Model: Do Auditors Increase Audit Fees in the Presence of Internal Control Deficiencies? Contemporary Accounting Research 25: 219-242.

Hosmer, D., and S. Lemeshow. 2000. Applied logistic regression. $2^{\text {nd }}$ edition. New York, NY: John Wiley \& Sons.

Hribar, P., and D. Nichols. 2007. The Use of Unsigned Earnings Quality Measures in Tests of Earnings Management. Journal of Accounting Research 45: 1017-1053.

Iliev, P. 2010. The Effect of SOX Section 404: Costs, Earnings Quality, and Stock Prices. The Journal of Finance 65: 1163-1196.

Jones, J. 1991. Earnings Management during Import Relief Investigations. Journal of Accounting Research 29: 193-228. 
Kelley, H. 1971. Causal schemata and the attribution process, in Jones, E., and Davis, K., Eds., Attribution: Perceiving the Causes of Behavior. Morristown, New Jersey: General Learning Press.

Kinney, W., and M. Shepardson. 2011. Do Control Effectiveness Disclosures Require SOX 404(B) Internal Control Audits? A Natural Experiment with Small U.S. Public Companies. Journal of Accounting Research 49: 413-448.

Kinney, W., R. Martin, and M. Shepardson. 2013. Reflections on a Decade of SOX 404(B) Audit Production and Alternatives. Accounting Horizons 27: 799-813.

Knechel, W., G. Krishnan, M.Pevzner, L. Shefchik, and U Velury. 2013. Audit Quality: Insights from the Academic Literature. Auditing: A Journal of Practice \& Theory 32: 385-421.

Kothari, S., A. Leone, and C. Wasley. 2005. Performance Matched Discretionary Accrual Measures. Journal of Accounting and Economics 39: 163-197.

KPMG. Comment Letter on PCAOB Rule Making Docket Matter No. 021: Proposed Auditing Standard, An Audit of Internal Control over Financial Reporting that is Integrated with an Audit of Financial Statements and Related Other Proposals. February 26, 2007. Available at https://pcaobus.org/Rulemaking/Documents/021/all.pdf.

Kunda, Z. 1990. The case for motivated reasoning. Psychological Bulletin 108 (3): 480-498.

Larcker, D. and A. Zakolyukina. 2012. Detecting Deceptive Discussions in Conference Calls. Journal of Accounting Research 50: 495-540.

Lopez, D. M., and G. F. Peters. 2012. The effects of workload compression on audit quality. Auditing: A Journal of Practice \& Theory 31 (November): 139-165.

Lu, H., G. Richardson, and S. Salterio. 2011. Direct and Indirect Effects of Internal Control Weaknesses on Accrual Quality: Evidence from a Unique Canadian Regulatory Setting. Contemporary Accounting Research 28: 675-707.

Matsumoto, D. 2002. Management's Incentives to Avoid Negative Earnings Surprises. The Accounting Review 77: 483-514.

McNichols, M. 2002. Discussion of the Quality of Accruals and Earnings: The Role of Accrual Estimation Errors. The Accounting Review 77: 61-69.

Nagy, A. 2010. Section 404 Compliance and Financial Reporting Quality. Accounting Horizons 24: $441-454$.

Palmrose, Z.-V., and S. Scholz. 2004. The Circumstances and Legal Consequences of NonGAAP Reporting: Evidence from Restatements. Contemporary Accounting Research 21: 139-180. 
Public Company Accounting Oversight Board (PCAOB). 2007. An Audit of Internal Control over Financial Reporting That Is Integrated with an Audit of Financial Statements. Auditing Standard No. 5 (AS5). Washington, DC: PCAOB.

Public Company Accounting Oversight Board (PCAOB). 2008. Report on the PCAOB's 2004, 2005, 2006, and 2007 Inspections of Domestic Annually Inspected Firms. PCAOB Release No. 2008-008. December 5. Washington, DC: PCAOB.

Public Company Accounting Oversight Board (PCAOB). 2009. Report on the First-Year Implementation of Auditing Standard No. 5, an Audit of Internal Control over Financial Reporting That Is Integrated with an Audit of Financial Statements. PCAOB Release No. 2009-006. (September 24). Washington, DC: PCAOB.

Public Company Accounting Oversight Board (PCAOB). 2012. Observations From 2010 Inspections Of Domestic Annually Inspected Firms Regarding Deficiencies In Audits Of Internal Control Over Financial Reporting. PCAOB Release No. 2012-006. (December 10, 2012). Washington, DC: PCAOB.

Public Company Accounting Oversight Board (PCAOB). 2013a. Staff Audit Practice Alert No. 11: Considerations for Audits of Internal Control Over Financial Reporting. (October 24).Washington, DC: PCAOB.

Public Company Accounting Oversight Board (PCAOB). 2013b. Key Note Address by Jay D. Hanson, Board Member, at Baruch College $12^{\text {th }}$ Annual Financial Reporting Conference. Available at: http://pcaobus.org/News/Speech/Pages/05022013_Hanson.aspx.

Public Company Accounting Oversight Board (PCAOB). 2015. Inspection Observations Related to PCAOB Risk Assessment Auditing Standards (No. 8 through No. 15). PCAOB Release No. 2015-007. Washington, DC: PCAOB.

Raghunandan, K., and D. Rama. 2006. SOX Section 404 Material Weakness Disclosures and Audit Fees. Auditing: A Journal of Practice \& Theory 25: 99-114.

Reichelt, K., and D. Wang. 2010. National and Office-Specific Measures of Auditor Industry Expertise and Effects on Audit Quality. Journal of Accounting Research 48: 647-686.

Reynolds, J., and J. Francis. 2000. Does Size Matter? The Influence of Large Clients on OfficeLevel Auditor Reporting Decisions. Journal of Accounting and Economics 30: 375-400.

Rice, S., and D. Weber. 2012. How Effective is Internal Control Reporting under SOX 404 ? Determinants of the (Non-) Disclosure of Existing Material Weaknesses. Journal of Accounting Research 50: 811-843.

Scholz, S. 2008. The Changing Nature and Consequences of Public Company Financial Restatements: 1997-2006. Washington, DC: The Department of the Treasury. 
Schroeder, J., and M. Shepardson. 2016. Do SOX 404 Control Audits and Management Assessments Improve Overall Internal Control System Quality? The Accounting Review 91: 1513-41.

Seidel, T. 2017. Auditors’ Response to Assessments of High Control Risk: Further Insights. Contemporary Accounting Research 34: 1340-1377.

Shumway, T. 2001. Forecasting bankruptcy more accurately: A simple hazard model. Journal of Business 74: 101-24.

Staw, B.M., 1976. Knee-deep in the big muddy: A study of escalating commitment to a chosen course of action. Organizational behavior and human performance, 16(1), pp.27-44.

Staw, B.M., 1981. The escalation of commitment to a course of action. Academy of management Review, 6(4), pp.577-587.

Tan, H-T. 1995. Effects of expectations, prior involvement, and review awareness on memory for audit evidence and judgment. Journal of Accounting Research 33 (Spring): 113-135.

U.S. Congress. 1934. Securities Exchange Act of 1934. Public Law No. 73 - 291. Washington, DC: Government Printing Office.

U.S. Congress. 1991. The Federal Deposit Insurance Corporation Act of 1991 (FDICIA). Pubic Law No. 102 - 242. Washington, DC: Government Printing Office.

U.S. Congress. 2002. The Sarbanes-Oxley Act of 2002 (SOX). Pubic Law No. 107 - 204. Washington, DC: Government Printing Office.

U.S. Securities and Exchange Commission (SEC). 2006. Considering the Effects of Prior Year. Misstatements When Quantifying Misstatements in Current Year Financial Statements. Staff Accounting Bulletin No. 108. Washington, D.C.: GPO.

U.S. Securities and Exchange Commission (SEC). 2016. SEC Proposes Amendments to Smaller Reporting Company Definition, 2016-131. Washington, DC: GPO.

Zhao, Y., J. C. Bedard, and R.Hoitash. 2017. SOX 404, Auditor Effort, and the Prevention of Financial Report Misstatements. Auditing: A Journal of Practice \& Theory 36 (4): 151177.

Zmijewski, M. 1984. Methodological Issues Related to the Estimation of Financial Distress Prediction Models. Journal of Accounting Research 22: 59-82. 


\begin{tabular}{|c|c|}
\hline \multicolumn{2}{|r|}{ APPENDIX } \\
\hline \multicolumn{2}{|r|}{ VARIABLE DEFINITIONS } \\
\hline \multicolumn{2}{|c|}{ DEPENDENT VARIABLES } \\
\hline$M W$ & $\begin{array}{l}\text { An indicator equal to } 1 \text { if the firm discloses or receives a SOX } 404 \text { (a) or (b) } \\
\text { material weakness report for non-accelerated and accelerated filers, respectively, } \\
\text { and } 0 \text { otherwise. }\end{array}$ \\
\hline MAT_MISSTATE & $\begin{array}{l}\text { An indicator variable equal to } 1 \text { if the current year financial statements contain a } \\
\text { material misstatement that is restated in the future periods and is accompanied by } \\
\text { an item } 4.028 \text {-K disclosure and } 0 \text { otherwise. Classification is based on } \\
\text { restatement data available in Audit Analytics. }\end{array}$ \\
\hline MISSTATE & $\begin{array}{l}\text { An indicator variable equal to } 1 \text { if the current year financial statements contain a } \\
\text { misstatement that is restated in the future periods and } 0 \text { otherwise. Classification is } \\
\text { based on restatement data available in Audit Analytics. Misstatements that are not } \\
\text { due to accounting issues or are related to option backdating and leases are } \\
\text { classified as non-misstatements for purposes of variable construction. }\end{array}$ \\
\hline ABSDCACC & $\begin{array}{l}\text { The absolute value of firm-year residuals obtained from a regression of working } \\
\text { capital accruals using a modified Jones model that controls for performance, } \\
\text { growth, lagged accruals, and non-linear effects of positive and negative cash flows } \\
\text { from operations, estimated for each industry-year with at least } 20 \text { observations, } \\
\text { following Schroeder and Shepardson (2016). }\end{array}$ \\
\hline \multicolumn{2}{|c|}{ TEST VARIABLES } \\
\hline INTEGRATED & $\begin{array}{l}\text { An indicator variable equal to } 1 \text { if the firm receives a SOX 404(b) audit opinion } \\
\text { based on data available from Audit Analytics, and } 0 \text { otherwise. }\end{array}$ \\
\hline ICAQ_L2 & $\begin{array}{l}\text { An indicator variable equal to } 1 \text { if } 1 \text { ) the firm receives a SOX 404(b) audit opinion } \\
\text { and 2) the ICFR disclosure indicates no material weakness, while the likelihood } \\
\text { model estimates at least one material weakness. }\end{array}$ \\
\hline \multicolumn{2}{|c|}{ CONTROL VARIABLES FOR MATERIAL WEAKNESS PREDICTION MODEL } \\
\hline LNMVE & Natural log of market value of equity (csho*prcc_f). \\
\hline LNAGE & Natural log of the number of years the firm has filed with the SEC per Compustat. \\
\hline LNBSEG & $\begin{array}{l}\text { Natural log of total business segments as available from the Compustat segment } \\
\text { file. }\end{array}$ \\
\hline FOREIGN & $\begin{array}{l}\text { An indicator variable equal to } 1 \text { if the firm discloses foreign sales, and } 0 \text { otherwise } \\
\text { (obtained from the Compustat footnote file). }\end{array}$ \\
\hline$M \& A$ & $\begin{array}{l}\text { An indicator variable equal to } 1 \text { if the firm discloses merger or acquisition } \\
\text { activity, and } 0 \text { otherwise (obtained from the Compustat footnote file). }\end{array}$ \\
\hline RESTRUCTURE & $\begin{array}{l}\text { An indicator variable equal to } 1 \text { if the firm records a restructuring charge during } \\
\text { the current year (rca), and } 0 \text { otherwise. }\end{array}$ \\
\hline ARINV & Receivables (rect) plus inventory (invt) divided by end-of-year assets (at). \\
\hline
\end{tabular}




\begin{tabular}{|c|c|}
\hline AGROWTH & $\begin{array}{l}\text { End-of-year assets less beginning-of-year assets divided by beginning-of-year } \\
\text { assets (at). }\end{array}$ \\
\hline CFO & Operating cash flows for the year (oancf) divided by end-of-year total assets. \\
\hline LOSS & $\begin{array}{l}\text { An indicator variable equal to } 1 \text { if the firm experiences a loss during the current } \\
\text { year (ib), and } 0 \text { otherwise. }\end{array}$ \\
\hline MBR & Market value of equity (csho*prcc_f) divided book value (at-lt). \\
\hline LIT & $\begin{array}{l}\text { An indicator variable equal to } 1 \text { if the firm is included in a high-risk industry as } \\
\text { defined by Matsumoto (2002), and } 0 \text { otherwise. High-risk industries are defined as } \\
\text { firms with SIC codes in the following industries: 2833-28366 (biotechnology); } \\
3570-3577 \text { and } 7370-7374 \text { (computers); 3600-3674 (electronics); and 5200-5961 } \\
\text { (retailing). }\end{array}$ \\
\hline$B I G N$ & $\begin{array}{l}\text { An indicator variable equal to } 1 \text { if the firm is audited by a Big } 4 \text { firm based on } \\
\text { Audit Analytics, and } 0 \text { otherwise. }\end{array}$ \\
\hline AUD_RESIGN & $\begin{array}{l}\text { An indicator variable equal to } 1 \text { if the firm experienced an auditor turnover from } \\
\text { year t- } 1 \text { to } t \text { due to an auditor initiated resignation, and } 0 \text { otherwise. Auditor } \\
\text { resignation determined based on Audit Analytics. }\end{array}$ \\
\hline ANC_RST & $\begin{array}{l}\text { An indicator variable equal to } 1 \text { if the firm announces a restatement during year } \mathrm{t} \text {, } \\
\text { and } 0 \text { otherwise (obtained from Audit Analytics). }\end{array}$ \\
\hline$P Y \_M W$ & $\begin{array}{l}\text { An indicator variable equal to } 1 \text { if the firm discloses or receives a SOX 404(a) } \\
\text { and/or 404(b) material weakness during the prior year, and } 0 \text { otherwise. }\end{array}$ \\
\hline \multicolumn{2}{|c|}{ CONTROLS FOR RESTATEMENT MODEL NOT ALREADY DEFINED ABOVE } \\
\hline LNASSETS & Natural log of total assets (at). \\
\hline ROA & $\begin{array}{l}\text { Income before extraordinary items (ib) divided by average total assets (at) for the } \\
\text { fiscal year. }\end{array}$ \\
\hline FNDSRSED & $\begin{array}{l}\text { An indicator variable equal to } 1 \text { if the sum of new long-term debt (dltis) plus new } \\
\text { equity (sstk) exceeds } 20 \text { percent of total assets (at), and } 0 \text { otherwise. }\end{array}$ \\
\hline BKMKT & Book value of equity (at-lt) divided by market value of equity (csho*prcc_f) \\
\hline QRATIO & Current assets (act) less inventory (invt) divided by total liabilities (lt). \\
\hline IINTCOV & $\begin{array}{l}\text { Interest expense (xint) divided by operating income before depreciation (oibdp) } \\
\text { with the ratio capped at a value of } 2.0 \text {. }\end{array}$ \\
\hline$L E V$ & Total liabilities (lt) divided by total assets (at). \\
\hline LNFEE & Natural log of total audit fees obtained from Audit Analytics. \\
\hline INSTPCT & $\begin{array}{l}\text { Percentage of shares held by institutions obtained from the Thomson Reuters 13-F } \\
\text { database. }\end{array}$ \\
\hline$B L K P C T$ & $\begin{array}{l}\text { Percentage of shares held by block holders with at least five percent ownership } \\
\text { obtained from the Thomson Reuters 13-F database. }\end{array}$ \\
\hline
\end{tabular}




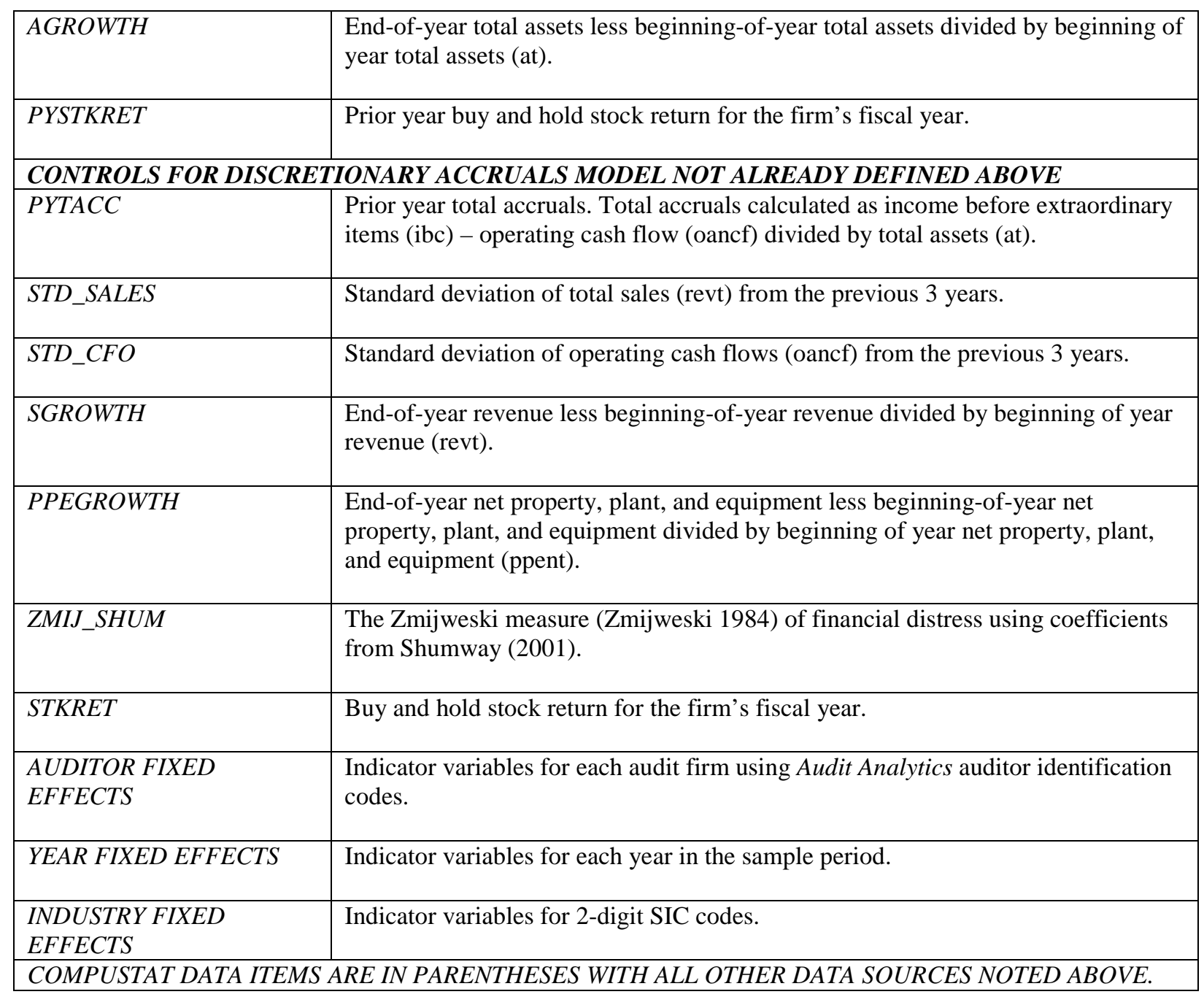


FIGURE 1

Low- versus High-Quality ICFR Disclosures

\begin{tabular}{|c|c|c|}
\hline Likely & $\begin{array}{c}\text { At least one Material } \\
\text { Weakness Disclosed }\end{array}$ & $\begin{array}{c}\text { No Material Weaknesses } \\
\text { Disclosed }\end{array}$ \\
\hline $\begin{array}{c}\text { At Least One Material } \\
\text { Weakness Likely }\end{array}$ & $\begin{array}{c}\text { 1. High-quality Material } \\
\text { Weakness Disclosure }\end{array}$ & $\begin{array}{c}\text { 2. Low-quality No Material } \\
\text { Weakness Disclosure } \\
\text { "Type II ICFR Disclosure } \\
\text { Error" }\end{array}$ \\
\hline $\begin{array}{c}\text { No Material Weaknesses } \\
\text { Likely }\end{array}$ & $\begin{array}{c}\text { ICAQ_L Low-quality Material } \\
\text { Weakness Disclosure } \\
\text { "Type I ICFR Disclosure } \\
\text { Error" }\end{array}$ & $\begin{array}{c}\text { 4. High-quality No Material } \\
\text { Weakness Disclosure }\end{array}$ \\
& ICAQ_L1 & ICAQ_H \\
\hline
\end{tabular}

To estimate ICFR disclosure quality, we use SOX Section 302 fourth quarter certifications, 404(a) management assessments and 404(b) audit reports to determine if a material weakness was disclosed. We then estimate whether a material weakness exists based on the following likelihood model:

$$
\begin{aligned}
& M W_{i, t}=\beta_{0}+\beta_{1} L_{N M V E_{i, t}}+\beta_{2} L_{N A G E_{i, t}}+\beta_{3} L_{N B S E G_{i, t}}+\beta_{4} \text { FOREIGN }_{i, t}+ \\
& \beta_{5} M \& A_{i, t}+\beta_{6} \text { RESTRUCTURE }_{i, t}+\beta_{7} \text { ARINV }_{i, t}+\beta_{8} \text { AGROWTH }_{i, t}+ \\
& \beta_{9} \text { CFO }_{i, t}+\beta_{10} \text { OOSS }_{i, t}+\beta_{11} M_{B R R_{i, t}}+\beta_{12} L I T_{i, t}+\beta_{13} B I G N_{i, t}+ \\
& \beta_{14} A U D \_R E S I G N_{i, t}+\beta_{15} A N C \_R S T_{i, t}+\beta_{16} P Y \_M W_{i, t}+ \\
& \beta_{17} I_{N T E G R A T E D}, t, t+\text { Industry Fixed Effects }+\varepsilon_{\mathrm{i}, \mathrm{t}}
\end{aligned}
$$

A firm is classified as ICAQ_H if we estimate at least one material weakness exists (does not exist) and one is (is not) reported. These groups are estimated to have high-quality ICFR disclosures. If we estimate at least one material weakness exists (does not exist) and one is not disclosed (is disclosed), the firm is classified as ICAQ_L2

(ICAQ_L1). ICAQ_L2 represents low-quality, Type II ICFR Disclosure Errors (i.e., under-assessments of CR). ICAQ_L1 represents low-quality ICFR disclosures due to Type I ICFR report errors, which will result in overassessment of control risk. This will likely lead to additional substantive testing, or inefficiencies. While we examine this subgroup for completeness, we note it is not the focus of our tests. 
TABLE 1

Material Weakness Expectations Model, Statistics, and Estimated Cut-off Probabilities

\begin{tabular}{|c|c|c|c|c|}
\hline \multicolumn{5}{|c|}{ Panel A: Example Model Output for 2007} \\
\hline LNMVE & -0.2239 & -4.27 & \multicolumn{2}{|l|}{$* * *$} \\
\hline LNAGE & -0.2864 & -2.61 & \multicolumn{2}{|l|}{$* * *$} \\
\hline LNBSEG & 0.1861 & 0.97 & \\
\hline FOREIGN & -0.0220 & -0.11 & \\
\hline$M \& A$ & 0.4176 & 2.00 & \multicolumn{2}{|l|}{ ** } \\
\hline RESTRUCTURE & 0.0051 & 0.02 & \\
\hline ARINV & 0.4798 & 1.54 & \\
\hline AGROWTH & 0.0596 & 1.30 & \\
\hline $\mathrm{CFO}$ & -0.0691 & -1.28 & \\
\hline LOSS & 0.4939 & 3.02 & \\
\hline$M B R$ & 0.0030 & 0.46 & & \\
\hline LIT & 0.0906 & 0.39 & & \\
\hline$B I G N$ & -0.4199 & -1.98 & $* *$ & \\
\hline AUD_RESIGN & 0.5015 & 1.77 & \multicolumn{2}{|c|}{$*$} \\
\hline$A N C \_R S T$ & 1.0446 & 5.99 & \multicolumn{2}{|l|}{$* * *$} \\
\hline$P Y \_M W$ & 1.5299 & 11.33 & \multicolumn{2}{|l|}{$* * *$} \\
\hline INTEGRATED & -0.1672 & -0.79 & \\
\hline Intercept & -1.7559 & -1.39 & \\
\hline \multicolumn{5}{|c|}{ Panel B: Expectations Model Statistics and Estimated Cut-off Probabilities by Year } \\
\hline & 2007 & 2008 & 2009 & 2010 \\
\hline Number of Observations & 1,735 & 2,004 & 1,720 & 1,455 \\
\hline Pseudo $\mathrm{R}^{2}$ & 0.174 & 0.202 & 0.272 & 0.350 \\
\hline ROC Curve & 0.782 & 0.808 & 0.844 & 0.874 \\
\hline \multirow{2}{*}{ Estimated cut-off probability } & 0.186 & 0.182 & 0.209 & 0.229 \\
\hline & 2011 & 2012 & \multicolumn{2}{|l|}{2013} \\
\hline Number of Observations & 1,498 & 1,463 & \multicolumn{2}{|l|}{1,281} \\
\hline Pseudo $\mathrm{R}^{2}$ & 0.373 & 0.395 & \multicolumn{2}{|l|}{0.410} \\
\hline ROC Curve & 0.889 & 0.891 & \multicolumn{2}{|l|}{0.895} \\
\hline Estimated cut-off probability & 0.157 & 0.181 & \multicolumn{2}{|l|}{0.298} \\
\hline \multicolumn{5}{|c|}{$\begin{array}{l}\text { Panel A: Results from the } 2007 \text { logistic regression of the dependent variable, } M W \text {, indicating whether } \\
\text { the firm disclosed at least one material weakness in the current year. The estimation model was } \\
\text { performed each year for purposes of calculating probabilities of material weakness existence, and to } \\
\text { identify the estimated cut-off probability points that maximize correct classification, as provided in Panel } \\
\text { B. } L N M V E=\text { natural log of the market value of equity, } L N A G E=\text { natural log of the age of the firm, } \\
L N B S E G=\text { natural log of the number of business segments, FOREIGN = } 1 \text { if the firm discloses foreign } \\
\text { sales, } M \& A=1 \text { if the firm discloses merger or acquisition activity, } R E S T R U C T U R E=1 \text { if the firms } \\
\text { records a restructuring charge, } A R I N V=\text { the sum of receivables and inventory scaled by total assets, } \\
A G R O W T H=\text { change in assets scaled by total assets, } C F O=\text { cash flow from operations scaled by total } \\
\text { assets, } L O S S=1 \text { if the firm experienced a loss during the current year, } M B R=\text { market value of equity } \\
\text { scaled by book value of equity, } L I T=1 \text { if the firm is in a high litigation-risk industry, BIGN }=1 \text { if the } \\
\text { firm is audited by a Big } 4 \text { audit firm, } A U D \_R E S I G N=1 \text { if the firm experienced an auditor resignation in } \\
\text { the prior year, } A N C \_R S T=1 \text { if the firm announced a restatement during the current year, } P Y \_M W=1 \text { if } \\
\text { the firm disclosed a material weakness in the prior year, INTEGRATED = } 1 \text { if the firm received an } \\
\text { integrated audit. } * * *, * *, * \text { indicate significance at the } 1 \% \text {, } 5 \% \text {, and } 10 \% \text { level, respectively, two-tailed. } \\
\text { Panel B: Model statistics for the material weakness expectations model, estimated by year, with } \\
\text { estimated cut-off probability points. }\end{array}$} \\
\hline
\end{tabular}


TABLE 2

Sample Selection

\begin{tabular}{lcc} 
& $\begin{array}{c}\text { Misstatement } \\
\text { Samples }\end{array}$ & $\begin{array}{c}\text { Discretionary } \\
\text { Accruals Sample }\end{array}$ \\
\hline $\begin{array}{l}\text { All U.S. Public Issuers from the intersection of Compustat and } \\
\text { Audit Analytics with market value of equity less than or equal to }\end{array}$ & 18,839 & $\mathbf{1 8 , 8 3 9}$ \\
$\begin{array}{l}\text { \$150 million for } 2007 \text { - } 2013 \\
\text { Less: Observations with SIC codes between } 6000 \text { to } 6999\end{array}$ & $(4,170)$ & $(4,170)$ \\
Less: Observations without the data necessary to compute the & & \\
control variables used in the multivariate analyses & $(5,604)$ & 7,977 \\
\cline { 2 - 2 } Total available observations for the multivariate analyses & & 9,065
\end{tabular}


TABLE 3

Univariate Statistics

Panel A: Misstatement Samples

\begin{tabular}{|c|c|c|c|c|c|c|}
\hline \multirow[b]{2}{*}{ Variables } & \multicolumn{3}{|c|}{$\begin{array}{l}\text { Integrated Audit Observations } \\
\qquad(\mathrm{n}=2,183)\end{array}$} & \multicolumn{3}{|c|}{$\begin{array}{c}\text { FS-only Audit Observations } \\
(\mathrm{n}=\mathbf{6 , 8 8 2})\end{array}$} \\
\hline & Mean & Median & SD & Mean & Median & SD \\
\hline MAT_MISSTATE & $0.046 *$ & $0.000 *$ & 0.209 & 0.033 & 0.000 & 0.179 \\
\hline MISSTATE & 0.099* & $0.000 *$ & 0.299 & 0.068 & 0.000 & 0.252 \\
\hline LNASSETS & $4.808^{*}$ & $4.831^{*}$ & 1.276 & 2.369 & 2.808 & 2.106 \\
\hline LOSS & $0.661^{*}$ & $1.000 *$ & 0.473 & 0.691 & 1.000 & 0.462 \\
\hline$R O A$ & $-0.213^{*}$ & $-0.065^{*}$ & 0.519 & -1.107 & -0.138 & 2.711 \\
\hline FNDSRSED & $0.287^{*}$ & $0.000 *$ & 0.452 & 0.316 & 0.000 & 0.465 \\
\hline$M \& A$ & 0.031 & 0.000 & 0.173 & 0.026 & 0.000 & 0.159 \\
\hline$B K M K T$ & $0.558 *$ & $0.684 *$ & 2.352 & -0.072 & 0.368 & 2.953 \\
\hline QRATIO & $2.942 *$ & $1.574 *$ & 4.251 & 2.329 & 1.055 & 4.607 \\
\hline IINTCOV & 0.066* & $0.006 *$ & 0.562 & -0.068 & 0.000 & 0.684 \\
\hline$L E V$ & $0.593^{*}$ & $0.482 *$ & 0.766 & 2.644 & 0.553 & 6.506 \\
\hline LNFEE & $13.156^{*}$ & $13.175^{*}$ & 0.842 & 11.719 & 11.788 & 1.000 \\
\hline$M W$ & 0.098* & $0.000 *$ & 0.297 & 0.264 & 0.000 & 0.441 \\
\hline ANC_RST & 0.088 & 0.000 & 0.283 & 0.096 & 0.000 & 0.294 \\
\hline INSTPCT & 0.333* & $0.334 *$ & 0.284 & 0.079 & 0.000 & 0.145 \\
\hline$B L K P C T$ & $0.153 *$ & $0.102 *$ & 0.172 & 0.040 & 0.000 & 0.098 \\
\hline AGROWTH & $0.020 *$ & $-0.049 *$ & 0.601 & 0.261 & -0.027 & 1.527 \\
\hline PYSTKRET & $0.082 *$ & -0.175 & 1.311 & 0.422 & -0.157 & 2.255 \\
\hline$B I G N$ & $0.572 *$ & $1.000 *$ & 0.495 & 0.113 & 0.000 & 0.316 \\
\hline
\end{tabular}

Panel B: Discretionary Accruals Sample

\begin{tabular}{|c|c|c|c|c|c|c|}
\hline \multirow[b]{2}{*}{ Variable } & \multicolumn{3}{|c|}{$\begin{array}{l}\text { Integrated Audit Observations } \\
(n=2,122)\end{array}$} & \multicolumn{3}{|c|}{$\begin{array}{l}\text { FS-only Audit Observations } \\
\qquad(\mathrm{n}=5,855)\end{array}$} \\
\hline & Mean & Median & SD & Mean & Median & SD \\
\hline$A B S D C A C C$ & 0.118* & $0.064 *$ & 0.167 & 0.194 & 0.085 & 0.286 \\
\hline LNASSETS & 4.799* & $4.815^{*}$ & 1.200 & 2.750 & 3.018 & 1.716 \\
\hline PYACC & $-0.125 *$ & $-0.067 *$ & 0.387 & -0.487 & -0.087 & 1.604 \\
\hline CFO & $-0.062 *$ & $0.026 *$ & 0.386 & -0.285 & -0.011 & 1.075 \\
\hline LOSS & 0.652 & 1.000 & 0.476 & 0.644 & 1.000 & 0.479 \\
\hline STD_SALES & $47.556 *$ & $14.335 *$ & 151.826 & 11.704 & 3.123 & 54.963 \\
\hline STD_CFO & $0.166^{*}$ & $0.059 *$ & 0.773 & 0.478 & 0.093 & 1.686 \\
\hline
\end{tabular}


TABLE 3 - CONTINUED

Univariate Statistics

Panel B: Discretionary Accruals Sample - (Continued)

\begin{tabular}{|c|c|c|c|c|c|c|}
\hline \multirow[b]{2}{*}{ Variables } & \multicolumn{3}{|c|}{$\begin{array}{l}\text { Integrated Audit Observations } \\
\qquad(n=2,122)\end{array}$} & \multicolumn{3}{|c|}{$\begin{array}{l}\text { FS-only Audit Observations } \\
\qquad(\mathrm{n}=5,855)\end{array}$} \\
\hline & Mean & Median & SD & Mean & Median & SD \\
\hline PPEGROWTH & $0.079 *$ & $-0.036^{*}$ & 0.757 & 0.146 & -0.058 & 1.172 \\
\hline BKMKT & $0.615^{*}$ & $0.719 *$ & 2.233 & 0.118 & 0.489 & 2.776 \\
\hline$L E V$ & $0.566 *$ & $0.451^{*}$ & 0.674 & 1.721 & 0.515 & 4.746 \\
\hline ZMIJ_SHUM & $-1.716^{*}$ & $-2.537 *$ & 5.455 & 5.816 & -2.217 & 31.357 \\
\hline LNBSEG & $0.952 *$ & $0.693 *$ & 0.379 & 0.898 & 0.693 & 0.348 \\
\hline FOREIGN & $0.259 *$ & $0.000 *$ & 0.438 & 0.149 & 0.000 & 0.356 \\
\hline STKRET & $-0.066^{*}$ & $-0.312 *$ & 1.308 & 0.335 & -0.137 & 2.032 \\
\hline$L I T$ & $0.417^{*}$ & $0.000 *$ & 0.493 & 0.389 & 0.000 & 0.487 \\
\hline$M W$ & $0.096 *$ & $0.000 *$ & 0.295 & 0.225 & 0.000 & 0.418 \\
\hline INSTPCT & $0.339 *$ & $0.339 *$ & 0.285 & 0.094 & 0.002 & 0.155 \\
\hline BLKPCT & $0.154^{*}$ & $0.109 *$ & 0.170 & 0.048 & 0.000 & 0.105 \\
\hline AGROWTH & $0.005^{*}$ & $-0.047^{*}$ & 0.533 & 0.114 & -0.024 & 1.000 \\
\hline PYSTKRET & $0.084 *$ & $-0.167^{*}$ & 1.302 & 0.347 & -0.146 & 2.067 \\
\hline
\end{tabular}

Panel C: Descriptive Statistics for Group Analyses

Likely High-Quality ICFR Disclosures

Likely Low-Quality ICFR Disclosures

\begin{tabular}{|c|c|c|c|c|c|c|c|c|}
\hline & \multicolumn{4}{|c|}{$\mathrm{E}(M W)=1$ and $M W=1$} & \multicolumn{4}{|c|}{$\underline{E}(M W)=1$ and $M W=0 \quad E(M W)=0$ and $M W=1$} \\
\hline & Integrated & FS-only & Integrated & FS-only & Integrated & FS-only & Integrated & FS-only \\
\hline MAT_MISSTATE Mean & $0.133^{*}$ & 0.059 & $0.023^{*}$ & 0.012 & $0.122 *$ & 0.060 & $0.139 *$ & 0.064 \\
\hline MISSTATE Mean & $0.222 *$ & 0.104 & $0.061^{*}$ & 0.027 & $0.244^{*}$ & 0.140 & $0.253^{*}$ & 0.118 \\
\hline Number of obs. & 135 & 1,537 & 1,715 & 3,840 & 254 & 1,225 & 79 & 280 \\
\hline Percent of Integrated / FS-Only Group & 0.06 & 0.22 & 0.78 & 0.56 & 0.12 & 0.18 & 0.04 & 0.04 \\
\hline ABSDCACC Mean & $0.135 *$ & 0.318 & $0.113^{*}$ & 0.145 & $0.137 *$ & 0.233 & $0.135^{*}$ & 0.213 \\
\hline Number of obs. & 127 & 1,069 & 1,672 & 3,546 & 246 & 990 & 77 & 250 \\
\hline Percent of Integrated / FS-Only Group & 0.06 & 0.18 & 0.79 & 0.61 & 0.11 & 0.17 & 0.04 & 0.04 \\
\hline
\end{tabular}

Panel A: Univariate statistics for variables in the material misstatement and misstatement samples. MAT_MISSTATE = 1 if current year financial statements contain a misstatement that is restated in a future period and the firm issues a $4.028-\mathrm{K}$, MISSTATE $=1$ if current year financial statements contain a 
misstatement that is restated in a future period, LNASSETS = natural log of total assets, $L O S S=1$ if the firm experienced a loss during the current year, $R O A=$ income before extraordinary items scaled by average total assets, $F N D S R S E D=1$ if current year financing activities exceed $20 \%$ of total assets, $M \& A=1$ if the firm discloses merger or acquisition activity, BKMKT = book value of equity scaled by market value of equity, $Q R A T I O=$ current assets less inventory scaled by total liabilities, IINTCOV = interest expense scaled by operating income before depreciation with a maximum value of 2 , $L E V=$ total liabilities scaled by total assets, $L N F E E$ = natural log of total audit fees, $M W=1$ if the firm disclosed at least one material weakness in the current year, $A N C \_R S T=1$ if the firm announced a restatement during the current year, INSTPCT = percentage of shares held by institutions, $B L K P C T=$ percentage of shares held by blockholders that own at least five percent of total shares, $A G R O W T H=$ change in total assets scaled by prior year total assets, $P Y S T K R E T=$ prior year buy and hold stock return. All continuous variables are winsorized at the $1^{\text {st }}$ and $99^{\text {th }}$ percentile. Difference in means and median tests that are significant at the $\mathrm{p}<$ 0.10 level are denoted with a *.

Panel B: Univariate statistics for the discretionary accruals sample. Variables contained in both Panel A and B are defined as in Panel A. ABSDCACC $=$ Absolute value of the residual obtained from the performance adjusted modified Jones model (Schroeder and Shepardson 2016), $P Y T A C C=$ Prior year total accruals, $C F O=$ cash flow from operations scaled by total assets, STD_SALES = standard deviation of total sales from the previous 3 years, STD_CFO = standard deviation of operating cash flows from the previous 3 years, $P P E G R O W T H$ = change in property, plant, and equipment, scaled by prior year property, plant, and equipment, $M B R=$ market value of equity scaled by book value of equity, ZMIJ_SHUM = the Zmijweski measure of financial distress using coefficients from (Shumway 2001), LNBSEG = natural log of the number of business segments, FOREIGN = 1 if the firm discloses foreign sales, STKRET = annual buy and hold stock return, $L I T=1$ if the firm is in a high litigation-risk industry. All continuous variables are winsorized at the $1^{\text {st }}$ and $99^{\text {th }}$ percentile. Difference in means and median tests that are significant at the $\mathrm{p}<0.10$ level are denoted with a *.

Panel C: Descriptive statistics for comparison groups as discussed in Section 3.1 and Figure 1, as determined by our expectation of whether there was at least one material weakness in the current period, $E(M W)$, and whether the firm disclosed a material weakness in the current period, $M W$. All continuous variables are winsorized at the $1^{\text {st }}$ and $99^{\text {th }}$ percentile. Difference in means and median tests between integrated and FS-only audits, within comparison groups, that are significant at the $\mathrm{p}<0.10$ level are denoted with $\mathrm{a}$ * 
TABLE 4

Likelihood Financial Statements are Misstated

Comparison of Integrated vs. FS-only Audits

\begin{tabular}{|c|c|c|c|c|c|c|c|c|c|}
\hline & & \multicolumn{4}{|c|}{$\begin{array}{l}\text { Materially Misstated } \\
\text { Financial Statements } \\
\text { (DV=MAT_MISSTATE) }\end{array}$} & \multicolumn{4}{|c|}{$\begin{array}{c}\text { Misstated } \\
\text { Financial Statements } \\
\text { (DV=MISSTATE) }\end{array}$} \\
\hline & & (1) & & (2) & & (3) & & (4) & \\
\hline & $\begin{array}{c}\text { Pred. } \\
\text { Sign }\end{array}$ & $\begin{array}{l}\text { Coef. } \\
\text { (z-stat }\end{array}$ & & $\begin{array}{c}\text { Coef. } \\
\text { (z-stat) }\end{array}$ & & $\begin{array}{c}\text { Coef. } \\
\text { (z-stat) }\end{array}$ & & $\begin{array}{c}\text { Coef. } \\
\text { (z-stat) }\end{array}$ & \\
\hline INTEGRATED & $+/-$ & $\begin{array}{r}0.7402 \\
(3.63)\end{array}$ & $* * *$ & $\begin{array}{r}\mathbf{0 . 6 1 6 0} \\
(2.90)\end{array}$ & $* * *$ & $\begin{array}{r}0.4851 \\
(3.26)\end{array}$ & $* * *$ & $\begin{array}{r}0.4197 \\
(2.74)\end{array}$ & $* * *$ \\
\hline ICAQ_L2 & + & & & $\begin{array}{r}0.7556 \\
(2.73)\end{array}$ & $* * *$ & & & $\begin{array}{r}0.4732 \\
(2.13)\end{array}$ & $* *$ \\
\hline LNASSETS & + & $\begin{array}{r}0.1780 \\
(2.48)\end{array}$ & $* *$ & $\begin{array}{r}0.1827 \\
(2.54)\end{array}$ & $* *$ & $\begin{array}{r}0.1963 \\
(3.53)\end{array}$ & $* * *$ & $\begin{array}{r}0.1987 \\
(3.57)\end{array}$ & $* * *$ \\
\hline LOSS & + & $\begin{array}{r}-0.0884 \\
(-0.55)\end{array}$ & & $\begin{array}{r}-0.1059 \\
(-0.66)\end{array}$ & & $\begin{array}{r}0.1323 \\
(1.18)\end{array}$ & & $\begin{array}{r}0.1223 \\
(1.09)\end{array}$ & \\
\hline$R O A$ & - & $\begin{array}{r}0.0150 \\
(0.38)\end{array}$ & & $\begin{array}{r}0.0147 \\
(0.37)\end{array}$ & & $\begin{array}{r}-0.0024 \\
(-0.08)\end{array}$ & & $\begin{array}{r}-0.0025 \\
(-0.08)\end{array}$ & \\
\hline FNDSRSED & + & $\begin{array}{r}0.6257 \\
(4.51)\end{array}$ & $* * *$ & $\begin{array}{r}0.6147 \\
(4.45)\end{array}$ & $* * *$ & $\begin{array}{r}0.2730 \\
(2.60)\end{array}$ & $* * *$ & $\begin{array}{r}0.2695 \\
(2.58)\end{array}$ & $* *$ \\
\hline$M \& A$ & + & $\begin{array}{r}-0.2053 \\
(-0.66)\end{array}$ & & $\begin{array}{r}-0.1944 \\
(-0.62)\end{array}$ & & $\begin{array}{r}0.1666 \\
(0.76)\end{array}$ & & $\begin{array}{r}0.1698 \\
(0.77)\end{array}$ & \\
\hline$B K M K T$ & + & $\begin{array}{r}0.0369 \\
(1.58)\end{array}$ & & $\begin{array}{r}0.0374 \\
(1.61)\end{array}$ & & $\begin{array}{r}0.0490 \\
(2.95)\end{array}$ & $* * *$ & $\begin{array}{r}0.0493 \\
(2.98)\end{array}$ & $* * *$ \\
\hline QRATIO & - & $\begin{array}{r}-0.0177 \\
(-1.07)\end{array}$ & & $\begin{array}{r}-0.0187 \\
(-1.15)\end{array}$ & & $\begin{array}{r}-0.0261 \\
(-1.87)\end{array}$ & $*$ & $\begin{array}{r}-0.0264 \\
(-1.91)\end{array}$ & $*$ \\
\hline IINTCOV & + & $\begin{array}{r}0.0894 \\
(0.89)\end{array}$ & & $\begin{array}{r}0.0876 \\
(0.87)\end{array}$ & & $\begin{array}{r}-0.0016 \\
(-0.02)\end{array}$ & & $\begin{array}{r}-0.0026 \\
(-0.04)\end{array}$ & \\
\hline$L E V$ & $+/-$ & $\begin{array}{r}0.0074 \\
(0.40)\end{array}$ & & $\begin{array}{r}0.0069 \\
(0.37)\end{array}$ & & $\begin{array}{r}0.0221 \\
(1.68)\end{array}$ & $*$ & $\begin{array}{r}0.0219 \\
(1.67)\end{array}$ & $*$ \\
\hline LNFEE & - & $\begin{array}{r}-0.0639 \\
(-0.46)\end{array}$ & & $\begin{array}{r}-0.0836 \\
(-0.60)\end{array}$ & & $\begin{array}{r}-0.1394 \\
(-1.45)\end{array}$ & & $\begin{array}{r}-0.1501 \\
(-1.55)\end{array}$ & \\
\hline$M W$ & + & $\begin{array}{r}0.9684 \\
(6.27)\end{array}$ & $* * *$ & $\begin{array}{r}1.0254 \\
(6.44)\end{array}$ & $* * *$ & $\begin{array}{r}0.7029 \\
(6.12)\end{array}$ & $* * *$ & $\begin{array}{r}0.7315 \\
(6.25)\end{array}$ & $* * *$ \\
\hline$A N C \_R S T$ & + & $\begin{array}{r}0.4938 \\
(3.11)\end{array}$ & $* * *$ & $\begin{array}{r}0.4349 \\
(2.73)\end{array}$ & $* * *$ & $\begin{array}{r}0.7187 \\
(6.19)\end{array}$ & $* * *$ & $\begin{array}{r}0.6860 \\
(5.86)\end{array}$ & $* * *$ \\
\hline INSTPCT & - & $\begin{array}{r}-1.8526 \\
(-2.40)\end{array}$ & $* *$ & $\begin{array}{r}-1.8869 \\
(-2.43)\end{array}$ & $* *$ & $\begin{array}{r}-0.9797 \\
(-2.03)\end{array}$ & $* *$ & $\begin{array}{r}-0.9876 \\
(-2.04)\end{array}$ & $* *$ \\
\hline$B L K P C T$ & - & $\begin{array}{r}0.5037 \\
(0.40)\end{array}$ & & $\begin{array}{r}0.5811 \\
(0.46)\end{array}$ & & $\begin{array}{r}0.3837 \\
(0.53)\end{array}$ & & $\begin{array}{r}0.4132 \\
(0.57)\end{array}$ & \\
\hline AGROWTH & + & $\begin{array}{r}0.0778 \\
(2.61)\end{array}$ & $* * *$ & $\begin{array}{r}0.0749 \\
(2.50)\end{array}$ & $* *$ & $\begin{array}{r}0.0869 \\
(3.69)\end{array}$ & $* * *$ & $\begin{array}{r}0.0855 \\
(3.62)\end{array}$ & $* * *$ \\
\hline PYSTKRET & $+/-$ & $\begin{array}{r}-0.0137 \\
(-0.54)\end{array}$ & & $\begin{array}{r}-0.0137 \\
(-0.54)\end{array}$ & & $\begin{array}{r}-0.0006 \\
(-0.03)\end{array}$ & & $\begin{array}{r}-0.0007 \\
(-0.04)\end{array}$ & \\
\hline Intercept & & $\begin{array}{r}-3.2973 \\
(-1.91)\end{array}$ & $*$ & $\begin{array}{r}-3.1818 \\
(-1.88)\end{array}$ & $*$ & $\begin{array}{r}-2.8635 \\
(-2.06)\end{array}$ & $* *$ & $\begin{array}{r}-2.7893 \\
(-2.03)\end{array}$ & $* *$ \\
\hline Auditor FE & & Yes & & Yes & & Yes & & Yes & \\
\hline Year FE & & Yes & & Yes & & Yes & & Yes & \\
\hline Industry FE & & Yes & & Yes & & Yes & & Yes & \\
\hline Obs & & 9,065 & & 9,065 & & 9,065 & & 9,065 & \\
\hline Pseudo $\mathrm{R}^{2}$ & & 0.086 & & 0.088 & & 0.061 & & 0.062 & \\
\hline ROC Curve & & 0.739 & & 0.742 & & 0.692 & & 0.693 & \\
\hline
\end{tabular}


Columns (1) and (2) present results of a logistic regression with the dependent variable of MAT_MISSTATE, indicating if current year financial statements contain a misstatement that is restated in a future period and the firm issues a 4.02 8-K. Columns (3) and (4) present results of a logistic regression with the dependent variable of MISSTATE, indicating if current year financial statements contain a misstatement that is restated in a future period. Columns (1) and (3) test whether integrated audits are associated with different financial statement audit quality than FS-only audits (H1). Columns (2) and (4) provide tests of whether lower FS audit quality is due to systematic overreliance (H2), low-quality ICFR audits (H3), or both. INTEGRATED = 1 if the firm received an integrated audit, $I C A Q \_L 2=1$ if the firm received an integrated audit and we estimate that it was low quality, LNASSETS = natural $\log$ of total assets, $L O S S=1$ if the firm experienced a loss during the current year, $R O A=$ income before extraordinary items scaled by average total assets, FNDSRSED = 1 if current year financing activities exceed $20 \%$ of total assets, $M \& A=1$ if the firm discloses merger or acquisition activity, $B K M K T=$ book value of equity scaled by market value of equity, $Q R A T I O=$ current assets less inventory scaled by total liabilities, IINTCOV= interest expense scaled by operating income before depreciation with a maximum value of $2, L E V=$ total liabilities scaled by total assets, $L N F E E$ = natural log of total audit fees, $M W=1$ if the firm disclosed at least one material weakness in the current year, $A N C \_R S T=1$ if the firm announced a restatement during the current year, INSTPCT = percentage of shares held by institutions, BLKPCT = percentage of shares held by blockholders that own at least five percent of total shares, AGROWTH = change in total assets scaled by prior year total assets, PYSTKRET = prior year buy and hold stock return. All continuous variables are winsorized at the $1^{\text {st }}$ and $99^{\text {th }}$ percentile. Standard errors are clustered by firm to compute z-statistics. ***, **, * indicate significance at the $1 \%, 5 \%$, and 10\% level, respectively, twotailed. 


\section{TABLE 5}

Likelihood Financial Statements are Misstated Comparison Across Expected and Actual Material Weakness Classifications

Panel A: Materially Misstated Financial Statements (DV=MAT_MISSTATE)

\begin{tabular}{|c|c|c|c|c|c|c|c|c|c|}
\hline & & \multicolumn{4}{|c|}{ Likely High-Quality ICFR Disclosures } & \multicolumn{4}{|c|}{ Likely Low-Quality ICFR Disclosures } \\
\hline & & \multicolumn{2}{|c|}{$\begin{array}{c}\mathrm{E}(\mathrm{MW})=1 \text { and } \\
M W=1\end{array}$} & \multicolumn{2}{|c|}{$\begin{array}{c}E(M W)=0 \text { and } \\
M W=0\end{array}$} & \multicolumn{2}{|c|}{$\begin{array}{c}\mathrm{E}(\mathrm{MW})=1 \text { and } \\
\mathrm{MW}=0\end{array}$} & \multicolumn{2}{|c|}{$\begin{array}{c}\mathrm{E}(\mathrm{MW})=0 \text { and } \\
M W=1\end{array}$} \\
\hline & $\begin{array}{c}\text { Pred. } \\
\text { Sign }\end{array}$ & $\begin{array}{c}\text { (1) } \\
\text { Coef. } \\
\text { (z-stat) }\end{array}$ & & $\begin{array}{c}\text { (2) } \\
\text { Coef. } \\
\text { (z-stat) }\end{array}$ & & $\begin{array}{c}\text { (3) } \\
\text { Coef. } \\
\text { (z-stat) }\end{array}$ & & $\begin{array}{c}\text { (4) } \\
\text { Coef. } \\
\text { (z-stat) }\end{array}$ & \\
\hline INTEGRATED & $+/-$ & $\begin{array}{r}0.6077 \\
(1.74)\end{array}$ & * & $\begin{array}{r}1.0271 \\
(3.52)\end{array}$ & $* * *$ & $\begin{array}{r}0.9618 \\
(2.66)\end{array}$ & $* * *$ & $\begin{array}{r}1.8806 \\
(2.25)\end{array}$ & $* *$ \\
\hline LNASSETS & + & $\begin{array}{r}0.2568 \\
(2.49)\end{array}$ & $* *$ & $\begin{array}{r}-0.3281 \\
(-2.44)\end{array}$ & $* *$ & $\begin{array}{r}0.3512 \\
(2.55)\end{array}$ & $* *$ & $\begin{array}{r}0.5809 \\
(2.17)\end{array}$ & $* *$ \\
\hline LOSS & + & $\begin{array}{r}-0.1377 \\
(-0.48)\end{array}$ & & $\begin{array}{r}-0.0484 \\
(-0.16)\end{array}$ & & $\begin{array}{r}-0.3068 \\
(-1.06)\end{array}$ & & $\begin{array}{r}-0.0228 \\
(-0.03)\end{array}$ & \\
\hline$R O A$ & - & $\begin{array}{r}0.0109 \\
(0.19)\end{array}$ & & $\begin{array}{r}0.2737 \\
(1.24)\end{array}$ & & $\begin{array}{r}-0.0701 \\
(-0.93)\end{array}$ & & $\begin{array}{r}0.1893 \\
(0.64)\end{array}$ & \\
\hline FNDSRSED & + & $\begin{array}{r}0.5885 \\
(2.48)\end{array}$ & $* *$ & $\begin{array}{r}0.5985 \\
(2.40)\end{array}$ & $* *$ & $\begin{array}{r}0.6190 \\
(2.41)\end{array}$ & $* *$ & $\begin{array}{r}0.9696 \\
(1.87)\end{array}$ & $*$ \\
\hline$M \& A$ & + & $\begin{array}{r}0.2821 \\
(0.56)\end{array}$ & & $\begin{array}{r}-0.1594 \\
(-0.21)\end{array}$ & & $\begin{array}{r}-0.6172 \\
(-0.95)\end{array}$ & & $\begin{array}{r}1.0917 \\
(0.63)\end{array}$ & \\
\hline BKMKT & + & $\begin{array}{r}0.0257 \\
(0.66)\end{array}$ & & $\begin{array}{r}0.0060 \\
(0.14)\end{array}$ & & $\begin{array}{r}0.0705 \\
(2.40)\end{array}$ & $* *$ & $\begin{array}{r}-0.1022 \\
(-1.64)\end{array}$ & \\
\hline QRATIO & - & $\begin{array}{r}0.0117 \\
(0.44)\end{array}$ & & $\begin{array}{r}-0.0512 \\
(-1.47)\end{array}$ & & $\begin{array}{r}-0.0148 \\
(-0.61)\end{array}$ & & $\begin{array}{r}-0.1059 \\
(-1.36)\end{array}$ & \\
\hline IINTCOV & + & $\begin{array}{r}-0.0116 \\
(-0.08)\end{array}$ & & $\begin{array}{r}0.1326 \\
(0.65)\end{array}$ & & $\begin{array}{r}0.0970 \\
(0.57)\end{array}$ & & $\begin{array}{r}0.1443 \\
(0.43)\end{array}$ & \\
\hline$L E V$ & $+/-$ & $\begin{array}{r}0.0111 \\
(0.48)\end{array}$ & & $\begin{array}{r}-0.0274 \\
(-0.69)\end{array}$ & & $\begin{array}{r}-0.0030 \\
(-0.08)\end{array}$ & & $\begin{array}{r}-0.0568 \\
(-0.81)\end{array}$ & \\
\hline LNFEE & - & $\begin{array}{r}-0.2178 \\
(-1.17)\end{array}$ & & $\begin{array}{r}0.4062 \\
(1.54)\end{array}$ & & $\begin{array}{r}-0.3253 \\
(-1.39)\end{array}$ & & $\begin{array}{r}-1.3710 \\
(-3.31)\end{array}$ & $* * *$ \\
\hline$A N C \_R S T$ & + & $\begin{array}{r}0.2524 \\
(1.08)\end{array}$ & & $\begin{array}{r}0.1452 \\
(0.23)\end{array}$ & & $\begin{array}{r}-0.2001 \\
(-0.79)\end{array}$ & & $\begin{array}{r}0.0483 \\
(0.06)\end{array}$ & \\
\hline INSTPCT & - & $\begin{array}{r}-0.6609 \\
(-0.52)\end{array}$ & & $\begin{array}{r}-3.2990 \\
(-2.72)\end{array}$ & $* * *$ & $\begin{array}{r}-2.2033 \\
(-1.52)\end{array}$ & & $\begin{array}{r}0.6165 \\
(0.20)\end{array}$ & \\
\hline$B L K P C T$ & - & $\begin{array}{r}1.0540 \\
(0.42)\end{array}$ & & $\begin{array}{r}2.3158 \\
(1.38)\end{array}$ & & $\begin{array}{r}0.9900 \\
(0.49)\end{array}$ & & $\begin{array}{r}-5.6720 \\
(-0.96)\end{array}$ & \\
\hline AGROWTH & + & $\begin{array}{r}0.0161 \\
(0.29)\end{array}$ & & $\begin{array}{r}0.2348 \\
(3.73)\end{array}$ & $* * *$ & $\begin{array}{r}0.0521 \\
(0.97)\end{array}$ & & $\begin{array}{r}-0.0720 \\
(-0.29)\end{array}$ & \\
\hline PYSTKRET & $+/-$ & $\begin{array}{r}-0.0431 \\
(-1.02)\end{array}$ & & $\begin{array}{r}-0.0205 \\
(-0.32)\end{array}$ & & $\begin{array}{r}0.0277 \\
(0.76)\end{array}$ & & $\begin{array}{r}-0.2945 \\
(-1.14)\end{array}$ & \\
\hline Intercept & & $\begin{array}{r}-12.7683 \\
(-6.19)\end{array}$ & $* * *$ & $\begin{array}{r}-20.4968 \\
(-6.86)\end{array}$ & $* * *$ & $\begin{array}{r}0.7386 \\
(0.28)\end{array}$ & & $\begin{array}{r}-4.2692 \\
(-1.06)\end{array}$ & \\
\hline Auditor FE & & Yes & & Yes & & Yes & & Yes & \\
\hline Year FE & & Yes & & Yes & & Yes & & Yes & \\
\hline Industry FE & & Yes & & Yes & & Yes & & Yes & \\
\hline Observations & & 1,672 & & 5,555 & & 1,479 & & 359 & \\
\hline Pseudo $\mathrm{R}^{2}$ & & 0.098 & & 0.111 & & 0.097 & & 0.303 & \\
\hline ROC Curve & & 0.744 & & 0.785 & & 0.740 & & 0.886 & \\
\hline
\end{tabular}

(Table Continued on Next Page) 
TABLE 5 - (CONTINUED)

Likelihood Financial Statements are Misstated

Comparison Across Expected and Actual Material Weakness Classifications

Panel B: Misstated Financial Statements (DV= MISSTATE)

\begin{tabular}{|c|c|c|c|c|c|}
\hline & \multicolumn{2}{|c|}{ Likely High-Quality ICFR Disclosures } & \multicolumn{2}{|c|}{ Likely Low-Quality ICFR Disclosures } \\
\hline & & $E(M W)=1$ and & $\begin{array}{c}E(M W)=0 \text { and } \\
M W=0\end{array}$ & $\begin{array}{c}E(M W)=1 \text { and } \\
M W=0\end{array}$ & $\begin{array}{c}E(M W)=0 \text { and } \\
M W=1\end{array}$ \\
\hline & & (1) & (2) & (3) & (4) \\
\hline & $\begin{array}{c}\text { Pred. } \\
\text { Sign }\end{array}$ & $\begin{array}{l}\text { Coef. } \\
\text { (z-stat) }\end{array}$ & $\begin{array}{l}\text { Coef. } \\
\text { (z-stat) }\end{array}$ & $\begin{array}{l}\text { Coef. } \\
\text { (z-stat) }\end{array}$ & $\begin{array}{l}\text { Coef. } \\
\text { (z-stat) }\end{array}$ \\
\hline INTEGRATED & $+/-$ & $\begin{array}{rl}0.4898 & * \\
(1.68) & \end{array}$ & $\begin{array}{rl}\mathbf{0 . 7 9 9 8} & * * * \\
(3.87) & \end{array}$ & $\begin{array}{rl}0.6252 & * * \\
(2.28) & \end{array}$ & $\begin{array}{rl}1.3220 & * * \\
(2.29) & \end{array}$ \\
\hline Controls & & Yes & Yes & Yes & Yes \\
\hline Auditor FE & & Yes & Yes & Yes & Yes \\
\hline Year FE & & Yes & Yes & Yes & Yes \\
\hline Industry FE & & Yes & Yes & Yes & Yes \\
\hline Observations & & 1,672 & 5,555 & 1,479 & 359 \\
\hline Pseudo $\mathrm{R}^{2}$ & & 0.067 & 0.075 & 0.095 & 0.217 \\
\hline ROC Curve & & 0.681 & 0.735 & 0.719 & 0.820 \\
\hline
\end{tabular}

Panel A: Results of logistic regressions with the dependent variable of MAT_MISSTATE indicating if current year financial statements contain a misstatement that is restated in a future period and the firm issues a 4.02 8-K, within comparison groups as discussed in Section 3 and Figure 1. Comparison groups determined by our expectation of whether there was at least one material weakness in the current period, $E(M W)$ and whether the firm disclosed a material weakness in the current period, MW. INTEGRATED = 1 if the firm received an integrated audit, LNASSETS $=$ natural $\log$ of total assets, $L O S S=1$ if the firm experienced a loss during the current year, $R O A=$ income before extraordinary items scaled by average total assets, FNDSRSED = 1 if current year financing activities exceed $20 \%$ of total assets, $M \& A=1$ if the firm discloses merger or acquisition activity, $B K M K T=$ book value of equity scaled by market value of equity, $Q R A T I O=$ current assets less inventory scaled by total liabilities, IINTCOV = interest expense scaled by operating income before depreciation with a maximum value of $2, L E V=$ total liabilities scaled by total assets, $L N F E E$ = natural log of total audit fees, $M W=1$ if the firm disclosed at least one material weakness in the current year, ANC_RST = 1 if the firm announced a restatement during the current year, INSTPCT = percentage of shares held by institutions, BLKPCT = percentage of shares held by blockholders that own at least five percent of total shares, AGROWTH = change in total assets scaled by prior year total assets, PYSTKRET = prior year buy and hold stock return.

Panel B: Results of logistic regressions with the dependent variable of MISSTATE indicating if current year financial statements contain a misstatement that is restated in a future period, within comparison groups as discussed in Section 3 and Figure 1.

All continuous variables are winsorized at the $1^{\text {st }}$ and $99^{\text {th }}$ percentile. Standard errors are clustered by firm to compute z-statistics. ***, **, * indicate significance at the $1 \%, 5 \%$, and $10 \%$ level, respectively, two-tailed. 


\begin{tabular}{|c|c|c|c|c|c|}
\hline \multicolumn{6}{|c|}{$\begin{array}{c}\text { TABLE } 6 \\
\text { Differences in Discretionary Accruals } \\
\text { Comparison of Integrated vs. FS-only Audits }\end{array}$} \\
\hline & $\begin{array}{c}\text { Pred. } \\
\text { Sign }\end{array}$ & $\begin{array}{c}\text { (1) } \\
\text { Coef. } \\
\text { (t-stat) }\end{array}$ & & $\begin{array}{c}\text { (2) } \\
\text { Coef. } \\
\text { (t-stat) }\end{array}$ & \\
\hline INTEGRATED & $+/-$ & $\begin{array}{r}0.0350 \\
(5.13)\end{array}$ & $* * *$ & $\begin{array}{r}0.0314 \\
(4.58)\end{array}$ & $* * *$ \\
\hline ICAQ_L2 & + & & & $\begin{array}{r}0.0301 \\
(2.26)\end{array}$ & $* *$ \\
\hline LNASSETS & - & $\begin{array}{l}-0.0364 \\
(-10.11)\end{array}$ & $* * *$ & $\begin{array}{l}-0.0366 \\
(-10.16)\end{array}$ & $* * *$ \\
\hline PYTACC & - & $\begin{array}{r}-0.0181 \\
(-2.87)\end{array}$ & $* * *$ & $\begin{array}{r}-0.0181 \\
(-2.87)\end{array}$ & $* * *$ \\
\hline CFO & - & $\begin{array}{r}-0.0012 \\
(-0.11)\end{array}$ & & $\begin{array}{r}-0.0011 \\
(-0.11)\end{array}$ & \\
\hline LOSS & + & $\begin{array}{r}0.0352 \\
(6.01)\end{array}$ & $* * *$ & $\begin{array}{r}0.0345 \\
(5.88)\end{array}$ & $* * *$ \\
\hline STD_SALES & + & $\begin{array}{r}0.0001 \\
(4.75)\end{array}$ & $* * *$ & $\begin{array}{r}0.0001 \\
(4.74)\end{array}$ & $* * *$ \\
\hline STD_CFO & + & $\begin{array}{r}0.0023 \\
(0.59)\end{array}$ & & $\begin{array}{r}0.0023 \\
(0.57)\end{array}$ & \\
\hline PPEGROWTH & $+/-$ & $\begin{array}{r}0.0060 \\
(1.35)\end{array}$ & & $\begin{array}{r}0.0060 \\
(1.35)\end{array}$ & \\
\hline$B K M K T$ & $+/-$ & $\begin{array}{r}-0.0005 \\
(-0.98)\end{array}$ & & $\begin{array}{r}-0.0005 \\
(-0.97)\end{array}$ & \\
\hline$L E V$ & - & $\begin{array}{r}0.0091 \\
(2.12)\end{array}$ & $* *$ & $\begin{array}{r}0.0090 \\
(2.11)\end{array}$ & $* *$ \\
\hline ZMIJ_SHUM & + & $\begin{array}{r}0.0002 \\
(0.25)\end{array}$ & & $\begin{array}{r}0.0002 \\
(0.26)\end{array}$ & \\
\hline LNBSEG & + & $\begin{array}{r}0.0042 \\
(0.60)\end{array}$ & & $\begin{array}{r}0.0040 \\
(0.57)\end{array}$ & \\
\hline FOREIGN & + & $\begin{array}{r}-0.0089 \\
(-1.36)\end{array}$ & & $\begin{array}{r}-0.0090 \\
(-1.37)\end{array}$ & \\
\hline STKRET & $+/-$ & $\begin{array}{r}0.0021 \\
(1.04)\end{array}$ & & $\begin{array}{r}0.0021 \\
(1.04)\end{array}$ & \\
\hline$L I T$ & $+/-$ & $\begin{array}{r}-0.0207 \\
(-2.28)\end{array}$ & $* *$ & $\begin{array}{r}-0.0207 \\
(-2.29)\end{array}$ & $* *$ \\
\hline$M W$ & + & $\begin{array}{r}0.0352 \\
(3.98)\end{array}$ & $* * *$ & $\begin{array}{r}0.0360 \\
(4.06)\end{array}$ & $* * *$ \\
\hline INSTPCT & - & $\begin{array}{r}-0.0280 \\
(-1.32)\end{array}$ & & $\begin{array}{r}-0.0286 \\
(-1.35)\end{array}$ & \\
\hline$B L K P C T$ & - & $\begin{array}{r}0.0243 \\
(0.82)\end{array}$ & & $\begin{array}{r}0.0268 \\
(0.90)\end{array}$ & \\
\hline AGROWTH & + & $\begin{array}{r}0.0403 \\
(4.92)\end{array}$ & $* * *$ & $\begin{array}{r}0.0403 \\
(4.92)\end{array}$ & $* * *$ \\
\hline PYSTKRET & + & $\begin{array}{r}0.0051 \\
(2.75)\end{array}$ & $* * *$ & $\begin{array}{r}0.0051 \\
(2.75)\end{array}$ & $* * *$ \\
\hline Intercept & & $\begin{array}{r}0.1070 \\
(3.86)\end{array}$ & $* * *$ & $\begin{array}{r}0.1082 \\
(3.86)\end{array}$ & $* * *$ \\
\hline Auditor, Year and Industry FE & & Yes & & Yes & \\
\hline Observations & & 7,977 & & 7,977 & \\
\hline Adjusted R ${ }^{2}$ & & 0.296 & & 0.296 & \\
\hline
\end{tabular}


Columns (1) and (2) present results of OLS regressions with the dependent variable of ABSDACC, the absolute value of the residual obtained from the performance adjusted modified Jones model (Schroeder and Shepardson 2016). Column (1) tests whether integrated audits are associated with different financial statement audit quality than FS-only audits (H1). Column (2) tests whether lower FS audit quality is due to systematic over-reliance (H2), lowquality ICFR audits (H3) or both. INTEGRATED = 1 if the firm received an integrated audit, ICAQ_L2 = 1 if the firm received an integrated audit and we estimate that it was low quality, LNASSETS = natural log of total assets, $P Y T A C C=$ Prior year total accruals, $C F O=$ cash flow from operations scaled by total assets, $L O S S=1$ if the firm experienced a loss during the current year, $S T D \_S A L E S$ = standard deviation of total sales from the previous 3 years, STD_CFO = standard deviation of operating cash flows from the previous 3 years, PPEGROWTH = change in property, plant, and equipment, scaled by prior year property, plant, and equipment, $B K M K T=$ book value of equity scaled by market value of equity, $L E V=$ total liabilities scaled by total assets, ZMIJ_SHUM = the Zmijweski measure of financial distress using coefficients from (Shumway 2001), LNBSEG = natural log of the number of business segments, FOREIGN = 1 if the firm discloses foreign sales, STKRET = annual buy and hold stock return, $L I T=1$ if the firm is in a high litigation-risk industry, $M W=1$ if the firm disclosed at least one material weakness in the current year, INSTPCT = percentage of shares held by institutions, BLKPCT = percentage of shares held by blockholders that own at least five percent of total shares, $A G R O W T H=$ change in total assets scaled by prior year total assets, PYSTKRET = prior year buy and hold stock return. All continuous variables are winsorized at the $1^{\text {st }}$ and $99^{\text {th }}$ percentile. Standard errors are clustered by firm to compute t-statistics. ${ }^{* * *}, * *, *$ indicate significance at the $1 \%, 5 \%$, and $10 \%$ level, respectively, two-tailed. 


\begin{tabular}{|c|c|c|c|c|c|c|c|c|c|}
\hline Com & arison & $\begin{array}{r}\text { Differe } \\
\text { Across Expe }\end{array}$ & $\begin{array}{l}\text { ence } \\
\text { ected }\end{array}$ & $\begin{array}{l}\text { TABLE } 7 \\
\text { Discretio } \\
\text { Actual M }\end{array}$ & $\begin{array}{l}\text { nary } \\
\text { ateri }\end{array}$ & $\begin{array}{l}\text { cruals } \\
\text { Weakness }\end{array}$ & Class & ations & \\
\hline & & Likely High- & Qual & CFR Disclo & sures & Likely Low- & Quali & CFR Disclost & Ires \\
\hline & & $\begin{array}{r}E(M W)=1 \\
M W=1\end{array}$ & and & $\begin{array}{r}E(M W)=0 \\
M W=0\end{array}$ & & $\begin{array}{r}\mathrm{E}(\mathrm{MW})=1 \\
\mathrm{MW}=\mathbf{0}\end{array}$ & & $\begin{array}{c}E(M W)=0 \\
M W=1\end{array}$ & \\
\hline & $\begin{array}{c}\text { Pred. } \\
\text { Sign }\end{array}$ & $\begin{array}{c}\text { (1) } \\
\text { Coef. } \\
\text { (t-stat) }\end{array}$ & & $\begin{array}{c}\text { (2) } \\
\text { Coef. } \\
\text { (t-stat) }\end{array}$ & & $\begin{array}{c}\text { (3) } \\
\text { Coef. } \\
\text { (t-stat) }\end{array}$ & & $\begin{array}{c}\text { (4) } \\
\text { Coef. } \\
\text { (t-stat) }\end{array}$ & \\
\hline INTEGRATED & $+/-$ & $\begin{array}{r}0.0108 \\
(0.45)\end{array}$ & & $\begin{array}{r}0.0293 \\
(4.12)\end{array}$ & $* * *$ & $\begin{array}{r}0.0315 \\
(1.87)\end{array}$ & * & $\begin{array}{r}0.0259 \\
(0.70)\end{array}$ & \\
\hline LNASSETS & - & $\begin{array}{r}-0.0445 \\
(-5.44)\end{array}$ & $* * *$ & $\begin{array}{r}-0.0286 \\
(-7.18)\end{array}$ & $* * *$ & $\begin{array}{r}-0.0427 \\
(-5.15)\end{array}$ & $* * *$ & $\begin{array}{r}-0.0001 \\
(-0.01)\end{array}$ & \\
\hline PYTACC & - & $\begin{array}{r}-0.0145 \\
(-1.60)\end{array}$ & & $\begin{array}{r}-0.0279 \\
(-2.03)\end{array}$ & $* *$ & $\begin{array}{r}-0.0197 \\
(-1.70)\end{array}$ & $*$ & $\begin{array}{r}-0.0734 \\
(-2.24)\end{array}$ & $* *$ \\
\hline CFO & - & $\begin{array}{r}0.0162 \\
(1.05)\end{array}$ & & $\begin{array}{r}-0.0414 \\
(-2.04)\end{array}$ & $* *$ & $\begin{array}{r}-0.0014 \\
(-0.07)\end{array}$ & & $\begin{array}{r}-0.1424 \\
(-2.77)\end{array}$ & $* * *$ \\
\hline LOSS & + & $\begin{array}{r}0.0473 \\
(2.32)\end{array}$ & $* *$ & $\begin{array}{r}0.0211 \\
(3.11)\end{array}$ & $* * *$ & $\begin{array}{r}0.0233 \\
(1.55)\end{array}$ & & $\begin{array}{r}-0.0152 \\
(-0.44)\end{array}$ & \\
\hline STD_SALES & + & $\begin{array}{r}0.0001 \\
(2.00)\end{array}$ & $* *$ & $\begin{array}{r}0.0001 \\
(3.74)\end{array}$ & $* * *$ & $\begin{array}{r}0.0001 \\
(2.07)\end{array}$ & $* *$ & $\begin{array}{r}-0.0000 \\
(-0.23)\end{array}$ & \\
\hline STD_CFO & + & $\begin{array}{r}-0.0040 \\
(-0.72)\end{array}$ & & $\begin{array}{r}0.0070 \\
(0.97)\end{array}$ & & $\begin{array}{r}0.0032 \\
(0.55)\end{array}$ & & $\begin{array}{r}0.0164 \\
(1.40)\end{array}$ & \\
\hline PPEGROWTH & $+/-$ & $\begin{array}{r}0.0134 \\
(1.33)\end{array}$ & & $\begin{array}{r}0.0065 \\
(0.98)\end{array}$ & & $\begin{array}{r}0.0071 \\
(0.78)\end{array}$ & & $\begin{array}{r}-0.0066 \\
(-0.69)\end{array}$ & \\
\hline BKMKT & $+/-$ & $\begin{array}{r}-0.0005 \\
(-0.60)\end{array}$ & & $\begin{array}{r}-0.0001 \\
(-0.10)\end{array}$ & & $\begin{array}{r}-0.0002 \\
(-0.19)\end{array}$ & & $\begin{array}{r}-0.0007 \\
(-0.33)\end{array}$ & \\
\hline$L E V$ & - & $\begin{array}{r}0.0118 \\
(2.42)\end{array}$ & $* *$ & $\begin{array}{r}-0.0002 \\
(-0.02)\end{array}$ & & $\begin{array}{r}0.0107 \\
(1.16)\end{array}$ & & $\begin{array}{r}0.0104 \\
(0.85)\end{array}$ & \\
\hline ZMIJ_SHUM & + & $\begin{array}{r}-0.0006 \\
(-0.85)\end{array}$ & & $\begin{array}{r}0.0023 \\
(1.79)\end{array}$ & * & $\begin{array}{r}-0.0002 \\
(-0.12)\end{array}$ & & $\begin{array}{r}0.0004 \\
(0.19)\end{array}$ & \\
\hline LNBSEG & + & $\begin{array}{r}-0.0513 \\
(-2.36)\end{array}$ & $* *$ & $\begin{array}{r}0.0078 \\
(1.17)\end{array}$ & & $\begin{array}{r}0.0106 \\
(0.52)\end{array}$ & & $\begin{array}{r}0.0279 \\
(0.92)\end{array}$ & \\
\hline FOREIGN & + & $\begin{array}{r}0.0154 \\
(0.57)\end{array}$ & & $\begin{array}{r}-0.0084 \\
(-1.40)\end{array}$ & & $\begin{array}{r}0.0018 \\
(0.10)\end{array}$ & & $\begin{array}{r}-0.0159 \\
(-0.55)\end{array}$ & \\
\hline STKRET & $+/-$ & $\begin{array}{r}-0.0002 \\
(-0.04)\end{array}$ & & $\begin{array}{r}0.0047 \\
(1.77)\end{array}$ & * & $\begin{array}{r}0.0006 \\
(0.14)\end{array}$ & & $\begin{array}{r}-0.0043 \\
(-0.26)\end{array}$ & \\
\hline$L I T$ & + & $\begin{array}{r}-0.0487 \\
(-1.38)\end{array}$ & & $\begin{array}{r}-0.0202 \\
(-2.45)\end{array}$ & $* *$ & $\begin{array}{r}0.0065 \\
(0.30)\end{array}$ & & $\begin{array}{r}-0.0828 \\
(-1.71)\end{array}$ & $*$ \\
\hline INSTPCT & - & $\begin{array}{r}-0.0818 \\
(-1.05)\end{array}$ & & $\begin{array}{r}-0.0177 \\
(-0.77)\end{array}$ & & $\begin{array}{r}-0.0620 \\
(-1.05)\end{array}$ & & $\begin{array}{r}-0.0788 \\
(-0.72)\end{array}$ & \\
\hline$B L K P C T$ & - & $\begin{array}{r}-0.0703 \\
(-0.62)\end{array}$ & & $\begin{array}{r}0.0169 \\
(0.53)\end{array}$ & & $\begin{array}{r}0.1225 \\
(1.29)\end{array}$ & & $\begin{array}{r}-0.1266 \\
(-0.71)\end{array}$ & \\
\hline AGROWTH & + & $\begin{array}{r}0.0389 \\
(2.96)\end{array}$ & $* * *$ & $\begin{array}{r}0.0569 \\
(3.98)\end{array}$ & $* * *$ & $\begin{array}{r}0.0225 \\
(1.43)\end{array}$ & & $\begin{array}{r}0.0408 \\
(2.33)\end{array}$ & $* *$ \\
\hline PYSTKRET & + & $\begin{array}{r}-0.0013 \\
(-0.37)\end{array}$ & & $\begin{array}{r}0.0064 \\
(2.79)\end{array}$ & $* * *$ & $\begin{array}{r}0.0106 \\
(2.18)\end{array}$ & $* *$ & $\begin{array}{r}0.0036 \\
(0.46)\end{array}$ & \\
\hline Intercept & & $\begin{array}{r}0.0122 \\
(0.20)\end{array}$ & & $\begin{array}{r}0.0978 \\
(3.15)\end{array}$ & $* * *$ & $\begin{array}{r}0.1158 \\
(2.29)\end{array}$ & $* *$ & $\begin{array}{r}0.1509 \\
(1.95)\end{array}$ & $*$ \\
\hline Auditor FE & & Yes & & Yes & & Yes & & Yes & \\
\hline Year FE & & Yes & & Yes & & Yes & & Yes & \\
\hline Industry FE & & Yes & & Yes & & Yes & & Yes & \\
\hline Observations & & 1,196 & & 5,218 & & 1,236 & & 327 & \\
\hline Adjusted $\mathrm{R}^{2}$ & & 0.319 & & 0.253 & & 0.309 & & 0.298 & \\
\hline
\end{tabular}

(Table Continued on Next Page) 
Results of OLS regressions with the dependent variable of ABSDACC, the absolute value of the residual obtained from the performance adjusted modified Jones model (Schroeder and Shepardson 2016), within comparison groups as discussed in Section 3.1 and Figure 1. Comparison groups determined by our expectation of whether there was at least one material weakness in the current period, $E(M W)$ and whether the firm disclosed a material weakness in the current period, MW. INTEGRATED = 1 if the firm received an integrated audit, LNASSETS = natural log of total assets, $P Y T A C C=$ Prior year total accruals, $C F O=$ cash flow from operations scaled by total assets, $L O S S=1$ if the firm experienced a loss during the current year, STD_SALES = standard deviation of total sales from the previous 3 years, STD_CFO = standard deviation of operating cash flows from the previous 3 years, $P P E G R O W T H=$ change in property, plant, and equipment, scaled by prior year property, plant, and equipment, $B K M K T=$ book value of equity scaled by market value of equity, $L E V=$ total liabilities scaled by total assets, ZMIJ_SHUM= the Zmijweski measure of financial distress using coefficients from (Shumway 2001), LNBSEG = natural log of the number of business segments, FOREIGN = 1 if the firm discloses foreign sales, STKRET = annual buy and hold stock return, $L I T=1$ if the firm is in a high litigation-risk industry, INSTPCT = percentage of shares held by institutions, BLKPCT = percentage of shares held by blockholders that own at least five percent of total shares, AGROWTH = change in total assets scaled by prior year total assets, PYSTKRET = prior year buy and hold stock return. All continuous variables are winsorized at the $1^{\text {st }}$ and $99^{\text {th }}$ percentile. Standard errors are clustered by firm to compute t-statistics. ***, **, * indicate significance at the $1 \%, 5 \%$, and $10 \%$ level, respectively, two-tailed. 
TABLE 8

Results Addressing Self-selection of Public Float

Panel A: Results for Sample with Available Public Float

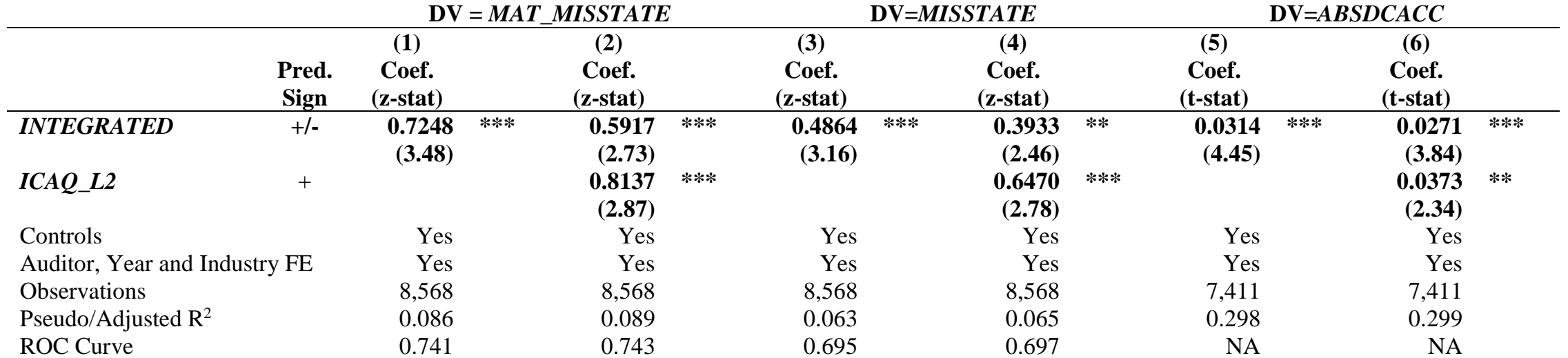

Panel B: Results Excluding Potential ICFR Audit Evaders

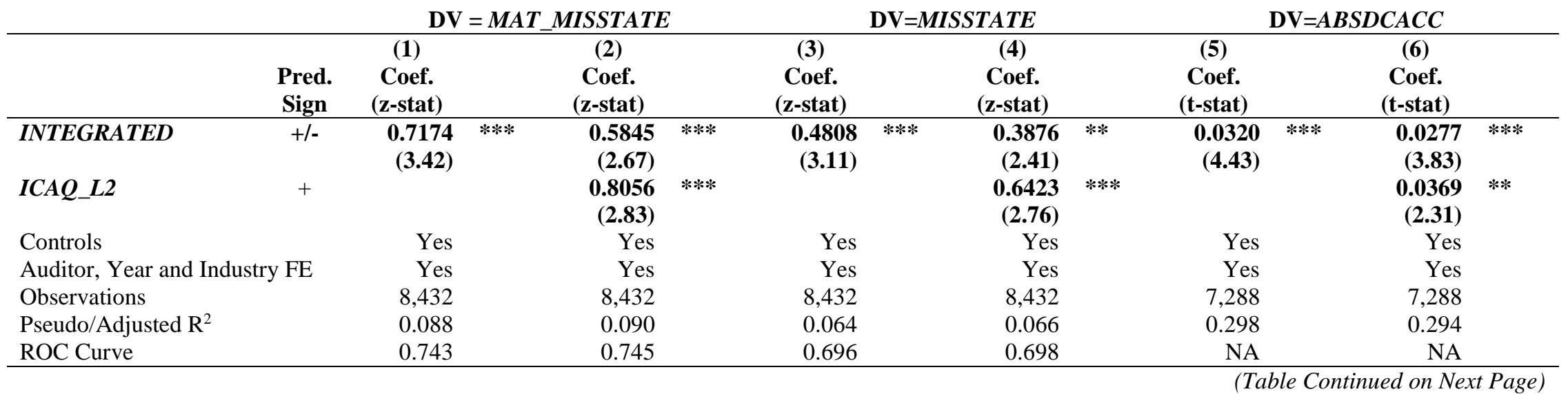


TABLE 8 - (CONTINUED)

Results Addressing Self-selection of Public Float

Panel C: Differences in Means for PSM Matching Covariates

\begin{tabular}{|c|c|c|c|c|c|c|}
\hline & \multicolumn{3}{|c|}{ Misstatements } & \multicolumn{3}{|c|}{ Discretionary Accruals } \\
\hline & Integrated & FS-Only & $\begin{array}{l}\text { Difference in } \\
\text { Means t-stat }\end{array}$ & Integrated & FS-Only & $\begin{array}{l}\text { Difference in } \\
\text { Means t-stat }\end{array}$ \\
\hline INSTPCT & 0.157 & 0.167 & 1.46 & 0.166 & 0.176 & 1.50 \\
\hline BLKPCT & 0.074 & 0.079 & 1.33 & 0.078 & 0.083 & 1.09 \\
\hline AGROWTH & 0.114 & 0.091 & -0.84 & 0.081 & 0.095 & 0.54 \\
\hline PYSTKRET & 0.228 & 0.250 & 0.42 & 0.219 & 0.254 & 0.67 \\
\hline
\end{tabular}

Panel D: Results of Sample Matched on Determinants of Public Float

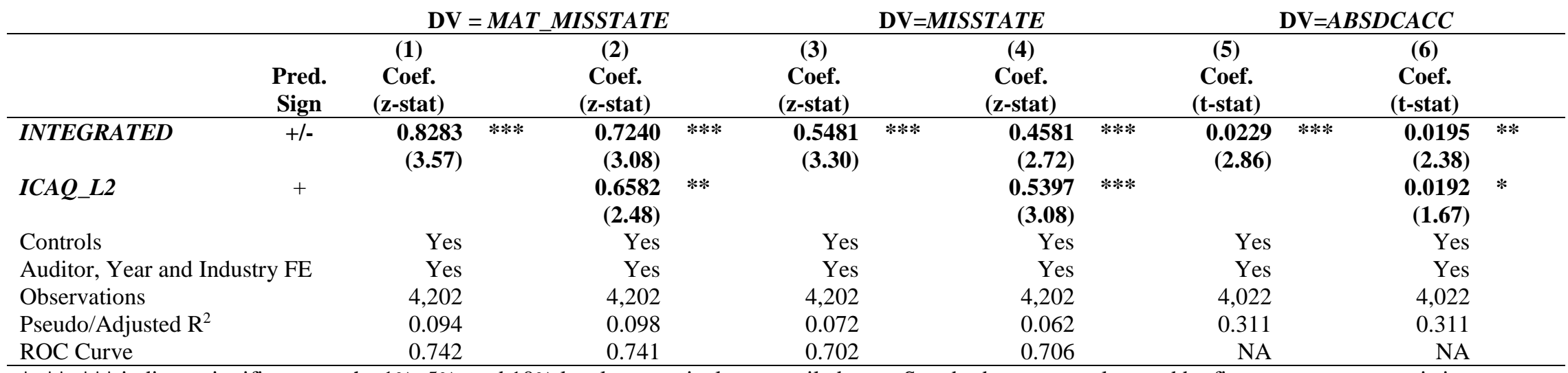

$*, * *, * * *$ indicate significance at the $1 \%, 5 \%$, and $10 \%$ level, respectively, two-tailed tests. Standard errors are clustered by firm to compute t-statistics.

Variable definitions can be found in the appendix. The sample period includes years 2007 to 2013. Panel A includes the sample for which we were able to collect public float information from the SEC 10-K filing. Panel B includes the sample that excludes potential ICFR audit evader observations. Panel C provides the difference in means tests for the covariates used to construct our PSM sample with Panel D providing empirical results using the PSM sample. 


\section{TABLE 9}

\section{Comparison of Pre vs. Post-Integrated Audits}

\begin{tabular}{|c|c|c|c|}
\hline Panel A: Material Misstated Fin & $\begin{array}{c}\text { cial Statements (DV=MA } \\
\text { Pre-Integrated Audits } \\
\text { (2001 to 2003) }\end{array}$ & $\begin{array}{l}\text { MISSTATE) } \\
\text { Post-Integrated Audits } \\
\text { (2007 to 2013) }\end{array}$ & \\
\hline $\begin{array}{l}\text { Pred. } \\
\text { Sign }\end{array}$ & $\begin{array}{c}\text { (1) } \\
\text { Coef. } \\
\text { (z-stat) }\end{array}$ & $\begin{array}{c}\text { (2) } \\
\text { Coef. } \\
\text { (z-stat) }\end{array}$ & $\begin{array}{c}(3) \\
\text { Cross-Model } \\
\text { Comparison } \chi^{2}\end{array}$ \\
\hline INTEGRATED & $\begin{array}{r}0.0630 \\
(0.27)\end{array}$ & $\begin{array}{rl}0.7402 & * * * \\
(3.63) & \end{array}$ & $4.94 * *$ \\
\hline $\begin{array}{l}\text { Controls, Auditor FE, Year FE } \\
\text { and Industry FE }\end{array}$ & Yes & Yes & \\
\hline Observations & 4,745 & 9,065 & \\
\hline Pseudo $\mathrm{R}^{2}$ / ROC & $0.115 / 0.752$ & $0.086 / 0.739$ & \\
\hline Panel B: Misstated Financial Sta & $\begin{array}{l}\text { ments (DV=MISSTATE) } \\
\text { Pre-Integrated Audits } \\
\text { (2001 to 2003) }\end{array}$ & $\begin{array}{l}\text { Post-Integrated Audits } \\
\text { (2007 to 2013) }\end{array}$ & \\
\hline $\begin{array}{c}\text { Pred. } \\
\text { Sign }\end{array}$ & $\begin{array}{c}\text { (1) } \\
\text { Coef. } \\
\text { (z-stat) }\end{array}$ & $\begin{array}{l}\text { (2) } \\
\text { Coef. } \\
\text { (z-stat) }\end{array}$ & $\begin{array}{c}(3) \\
\text { Cross-Model } \\
\text { Comparison } \chi^{2}\end{array}$ \\
\hline INTEGRATED & $\begin{array}{r}-0.1253 \\
(-0.71)\end{array}$ & $\begin{array}{rl}0.4851 & * * * \\
(3.26) & \end{array}$ & $7.15 * * *$ \\
\hline $\begin{array}{l}\text { Controls, Auditor FE, Year FE } \\
\text { and Industry FE }\end{array}$ & Yes & Yes & \\
\hline Observations & 4,948 & 9,065 & \\
\hline Pseudo R² / ROC & $0.062 / 0.676$ & $0.061 / 0.692$ & \\
\hline
\end{tabular}

\section{Panel C: Discretionary Accruals ( $\mathrm{DV}=A B S D C A C C)$}

Pre-Integrated Audits Post-Integrated Audits (2001 to 2003) (2007 to 2013)

\begin{tabular}{|c|c|c|c|c|}
\hline $\begin{array}{c}\text { Pred. } \\
\text { Sign }\end{array}$ & $\begin{array}{c}1) \\
\text { Coef. } \\
\text { (t-stat) }\end{array}$ & $\begin{array}{c}(2) \\
\text { Coef. } \\
\text { (t-stat) }\end{array}$ & $\begin{array}{r}(3) \\
\text { Cross-M } \\
\text { Comparis }\end{array}$ & \\
\hline INTEGRATED & $\begin{array}{r}0.0106 \\
(1.56)\end{array}$ & $\begin{array}{rl}\mathbf{0 . 0 3 5 0} & * * * \\
(5.13) & \end{array}$ & 6.28 & $* * *$ \\
\hline $\begin{array}{l}\text { Controls, Auditor FE, Year FE } \\
\text { and Industry FE }\end{array}$ & Yes & Yes & & \\
\hline Observations & 4,965 & 7,977 & & \\
\hline Adjusted $\mathrm{R}^{2}$ & 0.260 & 0.296 & & \\
\hline \multicolumn{5}{|c|}{$\begin{array}{l}\text { We compare coefficients between the pre- and post-integrated audit periods using seemingly unrelated estimation } \\
\text { in Stata. Column (1) includes observations from the pre-integration period when all audits were FS-only. Column (2) } \\
\text { includes the results from the primary analyses in Tables } 4 \text { and } 6 . M A T \_M I S S T A T E=1 \text { if current year financial } \\
\text { statements contain a misstatement that is restated in a future period and the firm issues a } 4.028-K, M I S S T A T E=1 \text { if } \\
\text { current year financial statements contain a misstatement that is restated in a future period, ABSDACC = the absolute } \\
\text { value of the residual obtained from the performance adjusted modified Jones model (Schroeder and Shepardson } \\
2016), I N T E G R A T E D=1 \text { if the firm receives an integrated audit. All continuous variables are winsorized at the } 1^{\text {st }} \\
\text { and } 99^{\text {th }} \text { percentile. Standard errors are clustered by firm to compute z-statistics. ***, **, * indicate the significance } \\
\text { at } 1 \%, 5 \% \text {, and } 10 \% \text { level, respectively, two-tailed. }\end{array}$} \\
\hline
\end{tabular}

